\title{
Synthesis and characterization of organometallic chalcones functionalized with a crown ether fragment. Spectroscopic and electrochemical behavior
}

\author{
Nicolás Agurto, ${ }^{\dagger}$ Tamara Maldonado,${ }^{\dagger}$ Fernando Godoy, ${ }^{*}{ }^{\dagger}$ Alejandra \\ Gómez, ${ }^{\dagger}$ Carlos P. Silva, ${ }^{\dagger}$ Jorge Pavez, ${ }^{\dagger}$ Guillermo Ferraudi, ${ }^{\ddagger 1}$ Allen \\ Oliver, ${ }^{\ddagger 2}$ A. Graham Lappin. ${ }^{\ddagger 2}$ \\ ${ }^{\dagger}$ Departamento de Química de los Materiales, Facultad de Química y Biología, \\ Universidad de Santiago de Chile, Casilla 40, Santiago, Chile \\ ${ }^{*}$ Notre Dame Radiation Laboratory, University of Notre Dame, IN 46556, United States of \\ America \\ ${ }^{2}$ Department of Chemistry and Biochemistry, University of Notre Dame, IN 46556, United \\ States of America
}

Corresponding authors: e-mail addresses: fernando.godoy@usach.cl 


\begin{abstract}
Organometallic chalcone complexes functionalized with a macrocyclic fragment $\left[\left(\eta^{5}-\right.\right.$ $\mathrm{C}_{5} \mathrm{H}_{4} \mathrm{C}(\mathrm{O}) \mathrm{CH}=\mathrm{CH}-4-$ benzo-15-crown-5)MLn] (ferrocenyl, cyrhetrenyl, and cymantrenyl) have been synthesized. The complexes are characterized by IR spectroscopy, ${ }^{1} \mathrm{H}$ and ${ }^{13} \mathrm{C}$ NMR spectroscopies, elemental analyses, and HR-MS. The stereochemistry for the chalcone compounds was determined using the ${ }^{1} \mathrm{H}$ and ${ }^{13} \mathrm{C}$ NMR spectroscopy data, which indicated that they are isolated as a single isomer $(E)$. In addition, the syntheses of the chalcone-imine derivatives are described, and they adopt an anti- $(E, E)$ conformation in solution, confirmed by the X-ray crystal structures in the solid state. The UV-Visible and electrochemical behavior of the organometallic complexes are reported.
\end{abstract}

Keywords: Organometallic chalcone and imine complexes, crown ether, crystal structures. 


\section{Introduction}

The intrinsic properties and potential applications of chalcone containing derivatives has become a focus of attention in recent years. In particular, the chemistry of organic and ferrocenyl chalcones has been well documented in the literature. ${ }^{1}$ These compounds have been used as precursors in new synthetic routes such as the synthesis of 1,5-diketones under free solvent conditions, ${ }^{2}$ cyanopyridine, ${ }^{3}$ and ferrocenyl pyrazolines. ${ }^{4}$ Moreover, in the last few decades chalconyl compounds have attracted attention for their broad range of biological activities as antidepressant, ${ }^{5}$ antihyperglycemic, ${ }^{6}$ antibacterial, ${ }^{7}$ antioxidant, ${ }^{8}$ antitumour, ${ }^{4}$ antimalarial, ${ }^{9}$ and anti-HIV ${ }^{10}$ reagents. Ferrocenyl-cymantrenyl heterobimetallic chalcones, synthetized by Chatterjee et. al., exhibit moderate antimalarial and antibacterial activity, ${ }^{11}$ while mononuclear cyrhetrenyl chalcones, have been shown to be more active than their ferrocene analogues, when tested in evaluation of in vitro antimalarial activity. ${ }^{12}$ Related to this activity, sensing systems are frequently composed of a signaling unit linked to a receptor, so that ion binding is determined by a measurable physical change. Considering the broad versatility of chalconyl compounds, there are few examples of their application as chemosensors. Delavaux-Nicot et al. have investigated a series of ferrocenyl chalcones, mono and 1,1'-disubstituted, functionalized with an amine moiety or an aza-macrocycle. ${ }^{13}$ These metallo-ligands have shown selectivity toward $\mathrm{Ca}^{2+}$ and $\mathrm{Ba}^{2+}$ in acetonitrile. Another important class of functionalized rhenium(I) complexes with aza-crown ether pendants, synthetized by Yam et al., exhibit a high specificity toward $\mathrm{Pb}(\mathrm{II}) .{ }^{14}$ Previously, our research group reported the synthesis of new cyrhetrenyl tricarbonyl complexes functionalized with 4'-benzo-crown or 2-methyl-crown ether 
fragments, bridged by an imine linker. The cyclic voltammograms showed positive anodic waves arising from the $\operatorname{Re}(\mathrm{II}) / \operatorname{Re}(\mathrm{I})$ redox process (I). It was concluded that the size of the crown ether did not change the anodic potential significantly. Nevertheless, the metal centered redox processes of complexes that possess a methylene moiety were shifted to positive potentials compared to a benzo group. ${ }^{15}$

In this work, we report the synthesis, X-ray structures and electrochemical and spectroscopic behaviour of new ferrocenyl, cyrhetrenyl and cymantrenyl complexes functionalized with 4'-benzo-15-crown-5 fragment. In addition we have included the synthesis of related species with a chalcone-imine as linker.

\section{Results and discussion.}

\subsection{Synthesis of the organometallic chalcones 2-3.}

The compounds were synthesized following a procedure similar to that described for ferrocenyl and cymantrenyl chalcone derivatives. ${ }^{11,16}$ It is based on the Claisen-Schmidt reaction involving the condensation of the organometallic ketones 1a-c and the corresponding crown ether or organic aldehydes Id-e (Scheme 1). Derivatives 2a-c and 3a were obtained by reaction of the corresponding precursors in the presence of $\mathrm{NaOH}$ and were dissolved in water/ethanol mixed solvent for greater solubility of the components. A modification of the experimental procedure was used for the preparation of the cyrhetrenyl derivative 3b. The carbanion containing solution was added dropwise to an ethanolic solution of terephthalaldehyde (Ie) over a period of $2 \mathrm{~h}$. in order to control the proportion of nucleophile generated. The general synthetic procedure leads to formation of the bimetallic derivative (3b'). 
Complexes $\mathbf{2}$ and $\mathbf{3}$ were purified by successive recrystallizations from hexane or $\mathrm{CH}_{2} \mathrm{Cl}_{2} /$ hexane and isolated as air stable solids. They are soluble in most of polar solvents, and their solutions are stable for weeks if kept under nitrogen. The IR spectra of $\mathbf{2}$ and $\mathbf{3}$ (in solid $\mathrm{KBr}$ ) exhibit carbonyl stretching at $v_{\mathrm{C}=\mathrm{O}} \sim 1650 \mathrm{~cm}^{-1}$. Compared to the starting material 1a-c, the absorption bands are shifted to lower frequencies due to greater conjugation brought about by the formation of the enone moiety. ${ }^{17} \mathrm{New}$ absorption bands appear at lower frequencies corresponding to the olefin moiety, i.e. a stretching centered at $\sim 1590 \mathrm{~cm}^{-1}\left(v_{\mathrm{C}=\mathrm{C}}\right)$. As expected, the $v_{\mathrm{C}=\mathrm{C}}$ band for the cyrhetrenyl derivatives $\mathbf{2} \mathbf{b}$ and $\mathbf{3 b}$, was observed at higher frequencies $\left(\sim 1595 \mathrm{~cm}^{-1}\right)$ when compared to the corresponding ferrocenyl derivatives $2 \mathbf{a}$ and $\mathbf{3 a}\left(\sim 1587 \mathrm{~cm}^{-1}\right)$, the result of an augmented electron density in the carbonyl group carbon (lower polarization). This increase in electron density is caused by the electron-withdrawing tendency of the cyrhetrenyl moiety.

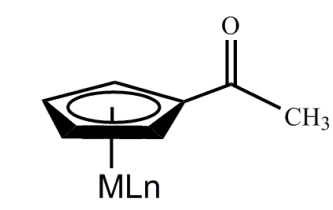

1a $\mathrm{MLn}=\mathrm{Fe}\left(\eta^{5}-\mathrm{C}_{5} \mathrm{H}_{5}\right)$

$\mathbf{1 b} \mathrm{MLn}=\operatorname{Re}(\mathrm{CO})_{3}$

1c $\mathrm{MLn}=\mathrm{Mn}(\mathrm{CO})_{3}$ $\mathrm{R}=$

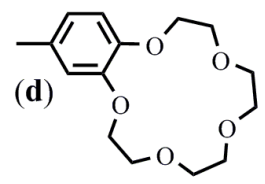

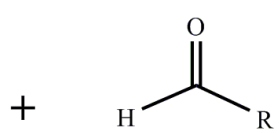

I

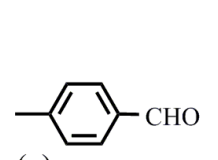

(e)

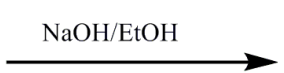

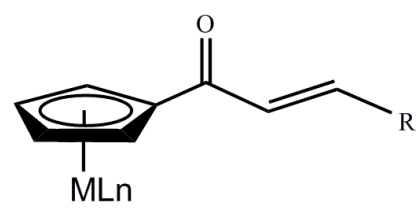

2a $M L n=F e\left(\eta^{5}-C_{5} H_{5}\right) \quad R=\mathbf{d}$

2b $\mathrm{MLn}=\operatorname{Re}(\mathrm{CO})_{3} \quad \mathrm{R}=\mathbf{d}$

2c $\operatorname{MLn}=\operatorname{Mn}(\mathrm{CO})_{3} \quad \mathrm{R}=\mathbf{d}$

3a $\mathrm{MLn}=\mathrm{Fe}\left(\eta^{5}-\mathrm{C}_{5} \mathrm{H}_{5}\right) \mathrm{R}=\mathbf{e}$

3b $\mathrm{MLn}=\operatorname{Re}(\mathrm{CO})_{3} \quad \mathrm{R}=\mathbf{e}$

Scheme 1

The ${ }^{1} \mathrm{H}$ NMR spectra (shown for $\mathbf{2 a}$ in Figure S1) revealed $E$-stereochemistry at the olefinic bond as evidenced by the coupling constant $\left({ }^{3} \mathrm{~J}_{\mathrm{HH}} \sim 15 \mathrm{~Hz}\right)$ of the two vinylic protons. This assignment is in agreement with the X-ray structure in the solid state. Moreover, the 
location of this resonance agrees with that reported in the literature for related organometallic chalcones having the $E$ isomer configuration. ${ }^{13 \mathrm{~b}, 18}$

An additional feature in the ferrocenyl derivatives $\mathbf{2 a}$ and $\mathbf{3 a}$, is a singlet centered at around $\delta 4.2$, which is assigned to a cyclopentadienyl $(\mathrm{Cp})$ proton, and two triplets between $\delta$ : 4.5-5.1 corresponding to the nonequivalent protons of the substituted pentagonal ring. Similarly, the half sandwich complexes: cyrhetrenyl (2b and $\mathbf{3 b}$ ) and cymantrenyl $\mathbf{2 c}$, display two sets of resonances for the protons of the $\mathrm{Cp}$ ligand. They are shifted to a higher frequency when compared with ferrocenyl analogs. ${ }^{11,12}$

The ${ }^{13} \mathrm{C}$ NMR spectra of $\mathbf{2}$ and $\mathbf{3}$ exhibited the two resonances around 120 and 140 ppm resulting from the olefinic carbons. To higher frequency, it is possible to observe the resonance of the ketonic group that is shifted $\Delta \delta \sim 10 \mathrm{ppm}$ in the ferrocenyl derivative compared to the analogous cyrhetrenyl. This can be explained when one considers the opposing electronic effects of these organometallic fragments. Similar results have been reported by Arancibia for a series of related chalcone complexes. By contrast, the terminal carbonyl ligands showed no noticeable shifts compared with each other and those reported for analogous derivatives. ${ }^{12}$

The complexes $\mathbf{2}$ and $\mathbf{3}$ also were characterized by high-resolution mass spectrometry and elemental analysis, and the values, reported in the Experimental Section, are in a good agreement with the proposed structures.

\subsection{Synthesis of the organometallic chalconyl-imines 4 .}

In an effort to explore the reactivity of the carboxaldehyde functionalized cyclopentadienyl complexes 3a-b were reacted with the precursor $4^{\prime}$-aminobenzo-15-crown-5 (IId). The 
reaction yields the corresponding organometallic chalconyl-imine crown ether complexes 4a-b (Scheme 2). A procedure similar to that described for the synthesis of related organometallic Schiff bases was followed for the preparation of $\mathbf{4 a - b} \cdot{ }^{15,19,20}$ The reaction mixtures were refluxed for $5 \mathrm{~h}$. After this time, the IR spectra showed the disappearance of the absorption bands corresponding to the starting material and the appearance of new bands from the corresponding imine group $\left(v_{\mathrm{C}=\mathrm{N}}\right.$ stretching $\left.1620 \mathrm{~cm}^{-1}\right)$. These spectral changes and those reported for the related complexes are in good agreement. ${ }^{21}$ It is also important to note that there is no significant difference in reactivity between ferrocenyl and cyrhetrenyl analogs. This can be rationalized if it is accepted that the formyl groups have similar electron densities, a condition that is supported by the identical chemical shifts shown by both precursor 3a-b ( $\delta: 10.05)$.

After purification, the complexes $\mathbf{4 a - b}$ were isolated as pure solid crystals in good yield $(\sim 80 \%)$ and characterized by spectroscopic techniques and X-ray crystallography (vide infra).

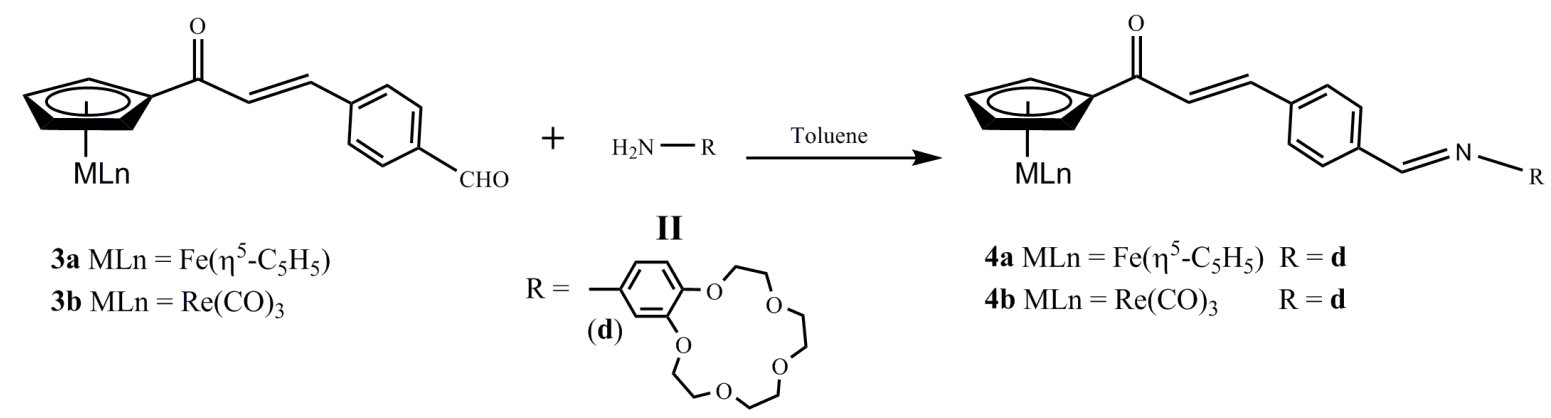

Scheme 2

The ${ }^{1} \mathrm{H}$ NMR spectra of $\mathbf{4 a - b}$ (Figures S18, S22) in $\left(\mathrm{CD}_{3}\right)_{2} \mathrm{SO}$ exhibits one singlet at about $8.7 \mathrm{ppm}$ assigned to iminic protons and two triplets associated with the Cp protons. Two additional doublets in the ${ }^{1} \mathrm{H}$ NMR spectra of these compounds confirm that in solution phase, the compounds maintain the isomeric form $(E)$ with respect to the precursors $\mathbf{3 a}-\mathbf{b}$. 
Furthermore, the ${ }^{13} \mathrm{C}$ NMR spectra of $\mathbf{4 a - b}$ show the same displacement and behavior shown in the spectra of the $\mathbf{2} \mathbf{a}-\mathbf{b}$ analogues. At lower frequencies, the ${ }^{13} \mathrm{C} N M R$ spectra exhibit a resonance around $157 \mathrm{ppm}$ assigned to the iminic carbon which is in good agreement with those in the spectra of related organometallic Schiff bases. ${ }^{22}$ The chalconeimine complexes were also characterized by high-resolution mass spectrometry and elemental analysis (data reported in the Experimental Section) whereas the structures of the latter complexes were also confirmed by X-ray crystallography.

\subsection{X-ray structures of $\mathbf{2 a}, \mathbf{2 b}, \mathbf{4 a}$ and $\mathbf{4 b}$.}

The molecular structures of the chalconyl metallo-ligands $\left(\eta^{5}-\mathrm{C}_{5} \mathrm{H}_{4} \mathrm{C}(\mathrm{O}) \mathrm{CH}=\mathrm{CH}-\right.$ benzo-15crown-5) $\mathrm{Fe}\left(\eta^{5}-\mathrm{C}_{5} \mathrm{H}_{5}\right) \quad$ (2a) and $\quad\left(\eta^{5}-\mathrm{C}_{5} \mathrm{H}_{4} \mathrm{C}(\mathrm{O}) \mathrm{CH}=\mathrm{CH}-\mathrm{C}_{6} \mathrm{H}_{4} \mathrm{CH}=\mathrm{N}-\right.$ benzo-15-crown5)Fe $\left(\eta^{5}-\mathrm{C}_{5} \mathrm{H}_{5}\right)(\mathbf{4 a})$ are shown below in Figures 1 and 2, respectively. Table 1 reports the crystal structure and refinement data.

The complexes $\mathbf{2 a}$ and $\mathbf{4 a}$ crystallize in the triclinic space group P-1 exhibiting two molecules in the asymmetric unit of the primitive cell. In the case of $\mathbf{2 a}$, the two independent molecules primarily differ in their overall organization within the lattice. One molecule (complex Fe1) is well-behaved and exhibits no disorder. The second molecule (Fe2) shows considerable disorder in the crown ether ring. Examination of the atomic displacement ellipsoids reveals that the disorder is present in the benzene ring of the crown ether with elongated ellipses for C46 and C47 (see Figure S5). The disorder was modeled applying fixed site occupancies and comparing $U_{\text {iso }}$ values for the atoms. This resulted in a series of mixed occupancies ranging from 0.25 to 0.67 . Inspection of the electron density map shows a wide ribbon of poorly organized electron density about this ring. The model 
provided here for molecule 2 is the most reasonable. The disordered atoms were refined with isotropic atomic displacement parameters. ${ }^{23-25}$

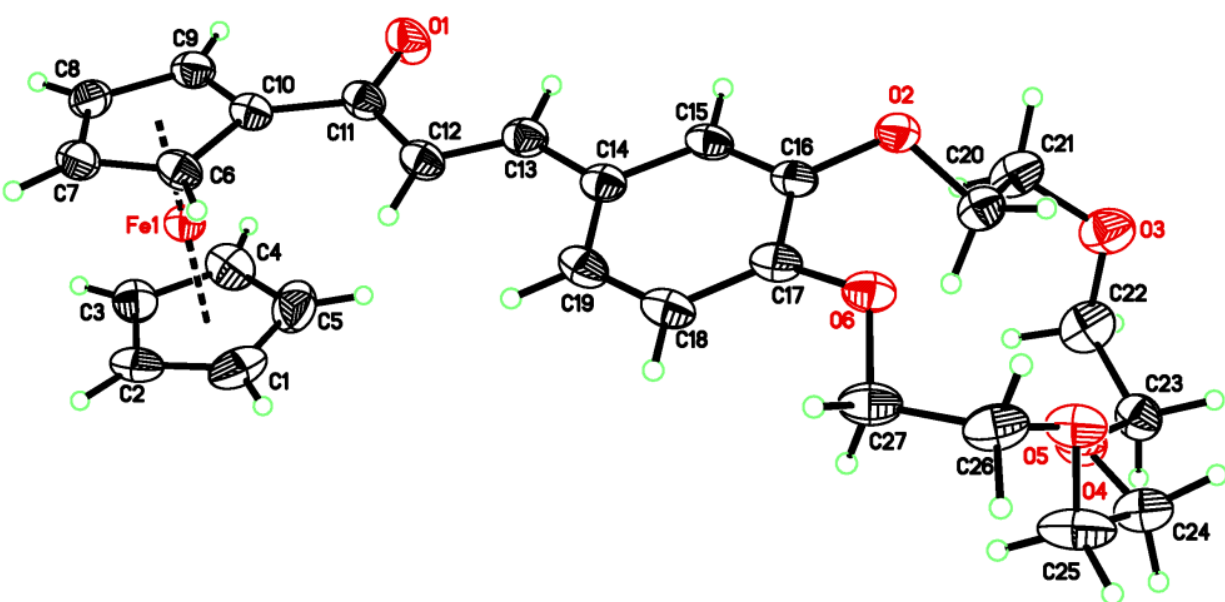

Figure 1. Molecular structure of $\left(\eta^{5}-\mathrm{C}_{5} \mathrm{H}_{4} \mathrm{C}(\mathrm{O}) \mathrm{CH}=\mathrm{CH}-\right.$ benzo-15-crown-5)Fe $\left(\eta^{5}-\mathrm{C}_{5} \mathrm{H}_{5}\right)$ (2a) drawn with $50 \%$ probability displacement ellipsoids. Hydrogen atoms included as spheres of arbitrary radius. Selected bond lengths (in $\AA$ ) and bond angle (in deg): C(10)$\mathrm{C}(11), 1.459(3) ; \mathrm{C}(11)-\mathrm{C}(12), 1.470(3) ; \mathrm{C}(11)-\mathrm{O}(1), 1.231(3) ; \mathrm{C}(12)-\mathrm{C}(13), 1.339(3)$; $\mathrm{C}(9)-\mathrm{C}(10)-\mathrm{C}(11), 124.2(2) ; \mathrm{C}(10)-\mathrm{C}(11)-\mathrm{C}(12), 119.7(2) ; \mathrm{O}(1)-\mathrm{C}(11)-\mathrm{C}(10), 119.6(2)$; $\mathrm{O}(1)-\mathrm{C}(11)-\mathrm{C}(12), 120.7(2) ; \mathrm{C}(13)-\mathrm{C}(12)-\mathrm{C}(11), 119.5(2)$.

On the other hand, the structure of $\mathbf{4 a}$ presents two complexes that are chemically identical and differ primarily in a small amount of disorder in the central phenyl ring of the tethering chain. The disorder was modeled with the phenyl- and imino-nitrogen rotated by approximately $180^{\circ}$ about the benzyl bond. The occupancies for the two components were 
refined and summed to unity yielding a ratio $0.82: 0.18$. The minor component was refined with isotropic displacement parameters.

The connectivities of the compounds $\mathbf{2 a}$ and $\mathbf{4 a}$ are as expected and consist of a ferrocenyl group, tethered to a benzo-15-crown-5 ring through a prop-2-en-1-one chain and methylimino-phenyl-butone chain, respectively. Bond distances and angles along the chain and within the molecule are as expected, and confirm the $E-E$ configuration assigned tentatively by NMR for both chalcone and imine groups. ${ }^{11,15}$

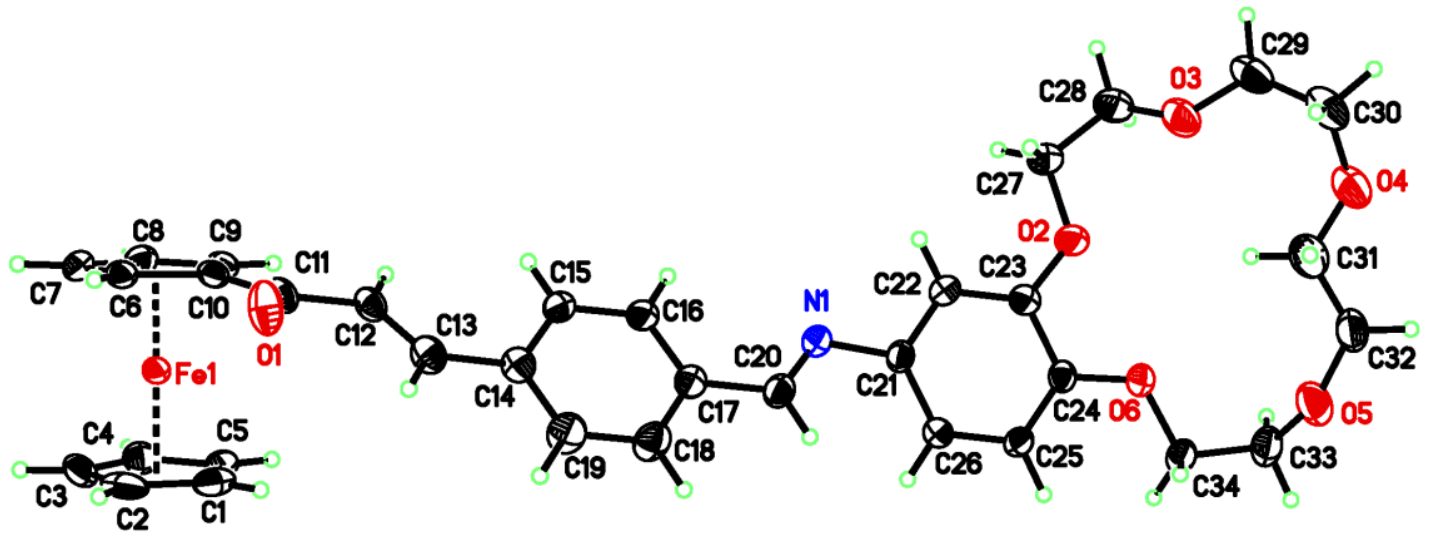

Figure 2. Molecular structure of $\left(\eta^{5}-\mathrm{C}_{5} \mathrm{H}_{4} \mathrm{C}(\mathrm{O}) \mathrm{CH}=\mathrm{CH}-\mathrm{C}_{6} \mathrm{H}_{4} \mathrm{CH}=\mathrm{N}-\right.$ benzo-15-crown5)Fe $\left(\eta^{5}-\mathrm{C}_{5} \mathrm{H}_{5}\right)(\mathbf{4 a})$ drawn with $50 \%$ probability displacement ellipsoids. Hydrogen atoms included as spheres of arbitrary radius. Selected bond lengths (in $\AA$ ) and bond angle (in deg): C(10)-C(11), 1.459(3); C(11)-C(12), 1.484(2); C(11)-O(1), 1.229(2); C(12)-C(13), $1.325(3) ; \quad \mathrm{C}(20-\mathrm{N}(1), \quad 1.272(2) ; \quad \mathrm{C}(9)-\mathrm{C}(10)-\mathrm{C}(11), \quad 127.14(15) ; \quad \mathrm{C}(10)-\mathrm{C}(11)-\mathrm{C}(12)$ 117.76(15); O(1)-C(11)-C(10), 121.35(16); O(1)-C(11)-C(12), 120.87(17); C(13)-C(12)C(11), 120.30(16). 
The molecular structures for cyrhetrenyl metallo-ligands $\left(\eta^{5}-\mathrm{C}_{5} \mathrm{H}_{4} \mathrm{C}(\mathrm{O}) \mathrm{CH}=\mathrm{CH}-\right.$ benzo-15crown-5) $\mathrm{Re}(\mathrm{CO})_{3}(\mathbf{2 b})$ and $\left(\eta^{5}-\mathrm{C}_{5} \mathrm{H}_{4} \mathrm{C}(\mathrm{O}) \mathrm{CH}=\mathrm{CH}-\mathrm{C}_{6} \mathrm{H}_{4} \mathrm{CH}=\mathrm{N}\right.$-benzo-15-crown-5) $\mathrm{Re}(\mathrm{CO})_{3}$ (4b) are shown below in Figures 3 and 4, respectively. Complex $\mathbf{2 b}$ crystallizes in the monoclinic space group $\mathrm{C} 2 / \mathrm{c}$ showing eight molecules of the complex and associated water of crystallization in the C-centered unit cell. Complex $\mathbf{4 b}$ crystallizes in the triclinic space group P-1 showing two molecules of the cyrhetrenyl complex and associated waters of crystallization in the primitive cell.

The structures of complexes $\mathbf{2 b}$ and $\mathbf{4 b}$ are as expected with the Re adopting a three-legged piano-stool geometry coordinated by the three carbonyl ligands and the cyclopentadienyl ligand. ${ }^{12,15,20,22}$ The crown ether is attached to the $\mathrm{Cp}$ ring via an allyl ester and benzylimine chain. For the case of $\mathbf{2 b}$, the water of crystallization is hydrogen-bonded to the benzo-15crown-5 ring through hydrogen bonds to $\mathrm{O} 4$ and O6. There are also close contacts to $\mathrm{O} 2$ and O3, however the water hydrogen atoms were located from a difference Fourier map and oriented more towards $\mathrm{O} 4$ and $\mathrm{O} 6$ as supported by the more obtuse O1w-H1w...O4/O6 angles (see description Figure 3). 


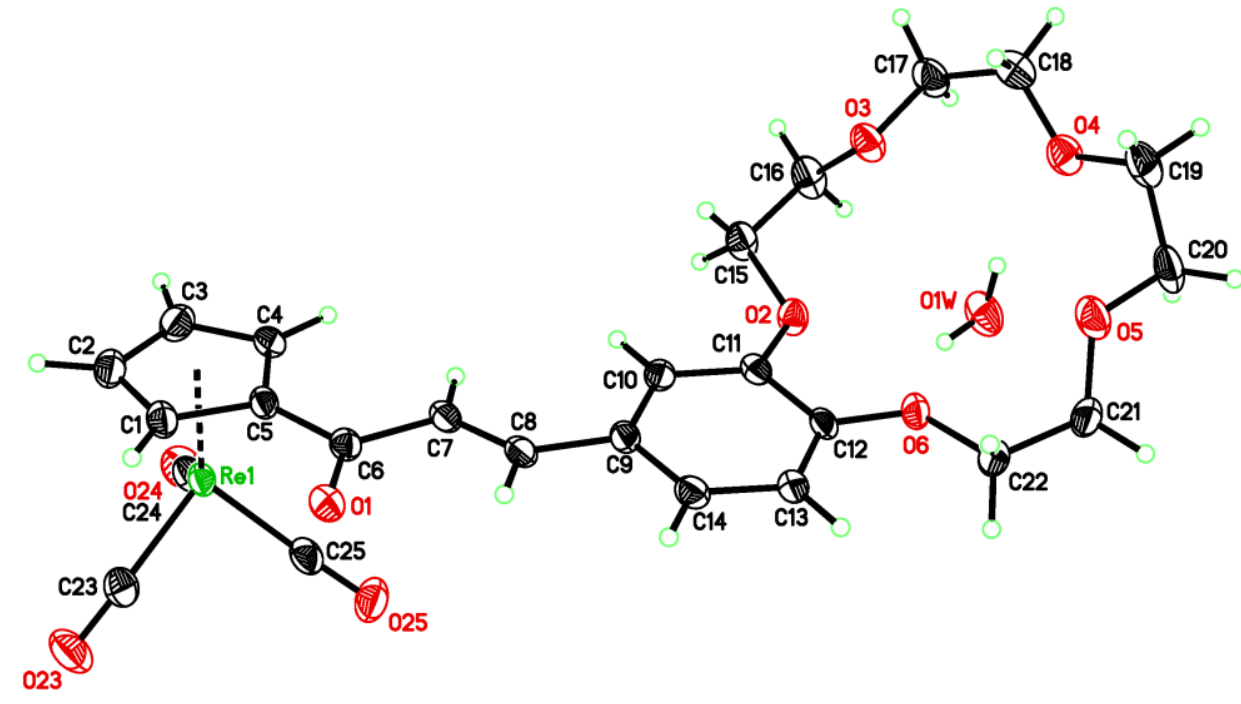

Figure 3. Molecular structure of $\left(\eta^{5}-\mathrm{C}_{5} \mathrm{H}_{4} \mathrm{C}(\mathrm{O}) \mathrm{CH}=\mathrm{CH}\right.$-benzo-15-crown-5) $\mathrm{Re}(\mathrm{CO})_{3}(\mathbf{2 b})$ drawn with $50 \%$ probability displacement ellipsoids. Hydrogen atoms included as spheres of arbitrary radius. Selected bond lengths (in $\AA$ ) and bond angle (in deg): $C(5)-C(6)$, 1.481(4); $\mathrm{C}(6)-\mathrm{O}(1), 1.223(3) ; \mathrm{C}(6)-\mathrm{C}(7), 1.470(3) ; \mathrm{C}(7)-\mathrm{C}(8), 1.333(4) ; \mathrm{C}(4)-\mathrm{C}(5)-\mathrm{C}(6)$, 128.5(2); $\mathrm{C}(7)-\mathrm{C}(6)-\mathrm{C}(5), 118.8(2) ; \mathrm{O}(1)-\mathrm{C}(6)-\mathrm{C}(5), 118.9(2) ; \mathrm{O}(1)-\mathrm{C}(7)-\mathrm{C}(6), 122.3(2)$; $\mathrm{C}(8)-\mathrm{C}(7)-\mathrm{C}(6), 117.9(2)$.

In the same context for $\mathbf{4 b}$, the water hydrogen atoms were located from a difference Fourier map and included in their observed positions. Coordinates were allowed to refine and the atomic displacement parameters were tied to that of $\mathrm{O} 1 \mathrm{~W}$. The hydrogen atoms are oriented towards $\mathrm{O} 3$ and $\mathrm{O} 5$ of the crown either and form good H-bond contacts to those atoms (see description Figure 4). 


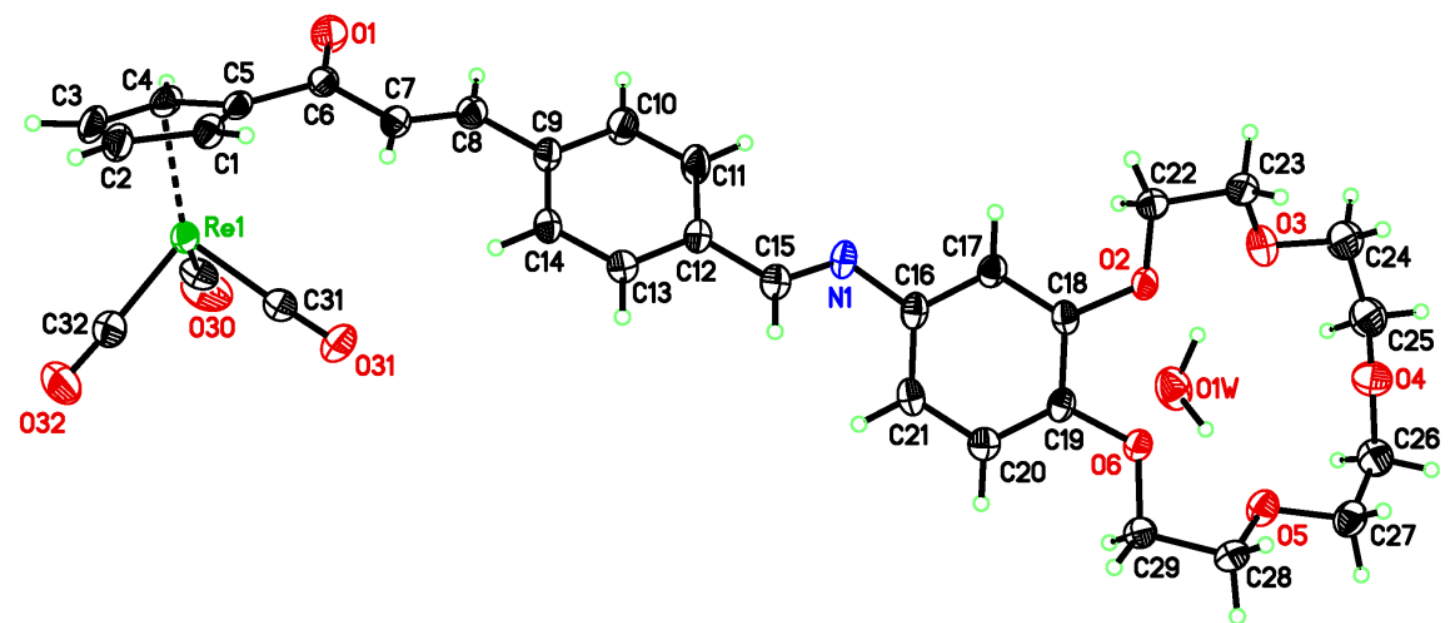

Figure 4. Molecular structure of $\left(\eta^{5}-\mathrm{C}_{5} \mathrm{H}_{4} \mathrm{C}(\mathrm{O}) \mathrm{CH}=\mathrm{CH}-\mathrm{C}_{6} \mathrm{H}_{4} \mathrm{CH}=\mathrm{N}-\right.$ benzo-15-crown-5) $\operatorname{Re}(\mathrm{CO})_{3}$ (4b) drawn with $50 \%$ probability displacement ellipsoids. Hydrogen atoms included as spheres of arbitrary radius. Selected bond lengths (in $\AA$ ) and bond angle (in deg): C(5)-C(6), 1.492(3); C(6)-O(1), 1.219(3); C(6)-C(7), 1.471(3); C(7)-C(8), 1.337(3); C(15)-N(1), 1.280(3); C(4)-C(5)-C(6), 123.5(2); C(7)-C(6)-C(5), 116.9(2); O(1)-C(6)-C(5), 119.2(2); O(1)-C(6)-C(7), 123.8(2); C(8)-C(7)-C(6), 121.5(2).

Bond distances and angles along the chain and within the molecule are as expected and confirm the $E-E$ configuration assigned tentatively by NMR for both chalcone and imine groups.

The cyrhetrenyl moiety in both structures exhibits a typical three-legged piano-stool type of geometry. In addition, the Re-CO distances and Re-C-O angles are similar to the values previously reported for cyclopentadienyl functionalized rhenium complexes. ${ }^{12,15,20,22}$ In addition, the $\mathrm{C}=\mathrm{N}$ bond lengths $(1.272$ and $1.280 \AA)$ for $\mathbf{4 a}$ and $\mathbf{4 b}$ respectively agree well with the values reported for cyrhetrenyl and ferrocenyl imines. ${ }^{15,20,26}$ 
Table 1. Crystal data and details of the refinement of the crystal structures of chalconyl and chalconyl imine complexes.

\begin{tabular}{|c|c|c|c|c|}
\hline & $2 a$ & $4 a$ & $2 b$ & $4 b$ \\
\hline $\begin{array}{l}\text { Empirical } \\
\text { formula }\end{array}$ & $\mathrm{C}_{27} \mathrm{H}_{30} \mathrm{FeO}_{6}$ & $\mathrm{C}_{34} \mathrm{H}_{35} \mathrm{FeNO}_{6}$ & $\mathrm{C}_{25} \mathrm{H}_{27} \mathrm{O}_{10} \mathrm{Re}$ & $\mathrm{C}_{32} \mathrm{H}_{32} \mathrm{NO}_{10} \mathrm{Re}$ \\
\hline Formula wt & 506.36 & 609.48 & 673.66 & 776.78 \\
\hline $\mathrm{T} / \mathrm{K}$ & $120(2)$ & $120(2)$ & $120(2)$ & $150(2)$ \\
\hline Cryst size/mm & $\begin{array}{l}0.444 \times 0.104 \times \\
0.068\end{array}$ & $\begin{array}{l}0.331 \times 0.215 \times \\
0.068\end{array}$ & $\begin{array}{l}0.193 \times 0.138 \times \\
0.138\end{array}$ & $\begin{array}{l}0.050 \times 0.050 \times \\
0.010\end{array}$ \\
\hline$\square / \AA$ & 0.71073 & 0.71073 & 0.71073 & 0.77490 \\
\hline Cryst syst & Triclinic & Triclinic & Monoclinic & Triclinic \\
\hline Space group & P-1 & P-1 & $\mathrm{C} 2 / \mathrm{c}$ & P-1 \\
\hline $\mathrm{a} / \AA$ & $12.4304(6)$ & $11.545(3)$ & 29.9992(12) & $8.3459(8)$ \\
\hline $\mathrm{b} / \AA$ & $12.7657(7)$ & $14.470(3)$ & $8.6293(3)$ & 10.6772(10) \\
\hline c/ $\AA$ & 16.7164(8) & $18.372(4)$ & 19.1882(7) & $18.3035(17)$ \\
\hline$\square / \mathrm{deg}$ & $67.651(2)$ & $87.593(6)$ & 90 & $85.021(3)$ \\
\hline$\square /$ deg & $69.878(2)$ & $72.768(6)$ & $91.840(2)$ & $83.474(3)$ \\
\hline$\square / \mathrm{deg}$ & $85.925(2)$ & $78.293(6)$ & 90 & $70.116(2)$ \\
\hline Volume/ $\AA^{3}$ & $2298.1(2)$ & $2869.8(11)$ & 4964.7(3) & $1521.8(2)$ \\
\hline $\mathrm{Z}$ & 4 & 4 & 8 & 2 \\
\hline $\mathrm{D}_{\text {cald }} / \mathrm{g} \mathrm{cm}^{-3}$ & 1.463 & 1.411 & 1.803 & 1.695 \\
\hline$\square / \mathrm{mm}^{-1}$ & 0.699 & 0.574 & 4.952 & 5.023 \\
\hline
\end{tabular}




\begin{tabular}{|l|l|l|l|l|}
\hline $\mathrm{F}(000)$ & 1064 & 1280 & 2656 & 772 \\
\hline $\mathrm{R}$ indices (all & $\mathrm{R}_{1}=0.0667$, & $\mathrm{R}_{1}=0.0473$, & $\mathrm{R}_{1}=0.0284$, & $\mathrm{R}_{1}=0.0246$, \\
data) & $\mathrm{wR}_{2}=0.1223$ & $\mathrm{wR}_{2}=0.1040$ & $\mathrm{wR}_{2}=0.0609$ & $\mathrm{wR}_{2}=0.0489$ \\
\hline $\begin{array}{l}\mathrm{R} \text { indices ( }> \\
2 \square(\mathrm{I}))\end{array}$ & $\begin{array}{l}\mathrm{R}_{1}=0.0447, \\
\mathrm{wR}_{2}=0.1113\end{array}$ & $\mathrm{R}_{1}=0.0368$, & $\mathrm{R}_{1}=0.0241$, & $\mathrm{R}_{1}=0.0206$, \\
& & $\mathrm{wR}_{2}=0.0592$ & $\mathrm{wR}_{2}=0.0476$ \\
\hline
\end{tabular}

2.4. Electrochemical behavior of organometallic complexes 2 and 4 .

As part of the interest in developing these compounds as sensors, the electrochemical properties of the chalcone 2a-c and chalcone-imine 4a-b complexes were investigated by cyclic voltammetry. Figure 5 shows the cyclic voltammograms (CVs) of the metalloligands recorded in dry acetonitrile containing $0.1 \mathrm{M}$ tetrabutylammonium tetrafluoroborate at a scan rate of $100 \mathrm{mV} / \mathrm{sec}$. To negative potentials, all of the compounds experienced the characteristic irreversible wave attributed to the reduction of the carbonyl $\mathrm{CO}$ group in the chalconyl fragment. This reduction process is shifted to less negative potentials in the presence of the electro-withdrawing organometallic fragment. A shift of $\approx 100 \mathrm{mV}$ in the carbonyl reduction is observed in the chalcone 2a-c CVs, while for the reduction in the CVs of the 4a-b compounds there is a greater shift toward less negative potentials. The larger shifts are attributed to an increased electron density caused by the presence of the benzo group in the organic fragment. ${ }^{13 c, 15}$ It is in the anodic potential range that the compounds exhibit the greater redox activity. There is a clear distinction between the redox behavior generated by the central metal of the organometallic fragment. Only the ferrocene complex shows a well-defined reversible redox process with $\mathrm{E}_{1 / 2}=0.73 \mathrm{~V}$ and $0.76 \mathrm{~V}$ for $\mathbf{2 a}$ and $\mathbf{4 a}$ compounds respectively. The cyrhetrene complex $\mathbf{2 b}$ shows an irreversible $\operatorname{Re}(\mathrm{II}) / \operatorname{Re}(\mathrm{I})$ 
anodic wave, ${ }^{15}$ while the manganese complex $2 \mathbf{c}$ shows no metal-centered redox process in the $0-2 \mathrm{~V}$ anodic potential range. ${ }^{27}$ The $\mathrm{CV}$ s of the chalcone imine complexes $\mathbf{4 a}$ and $\mathbf{4 b}$ exhibit irreversible anodic waves centered at $1.25 \mathrm{~V}$. They can be assigned to the oxidation of the organic imine moiety. Similar redox processes have been observed under the same experimental conditions with cyrhetrenyl tricarbonyl complexes functionalized with 4'benzo-crown ether fragments bridged with an imine linker. ${ }^{15}$ In the case of $\mathbf{4 a}$ and $\mathbf{4 b}$, the potential for oxidation of the imine moiety appears shifted to more positive values because of a more extensive electronic delocalization. This is a result of inserting the additional electron-rich benzo fragment linked to the imine group at the linker. It should be noted that both benzo planes are close to coplanarity with the imine carbonyl. Near the anodic limit of the potential sweep, redox processes due to the irreversible oxidation of the crown ether fragments are observed in all of the CVs of the complexes. ${ }^{13 b}$ In case of the cyrhetrene derivative $\mathbf{4 b}$ this irreversible oxidation wave may also include a contribution from the $\operatorname{Re}(\mathrm{II}) / \operatorname{Re}(\mathrm{I})$ couple where the potential experiences the positive shift associated with the larger electronic delocalization mentioned above. 


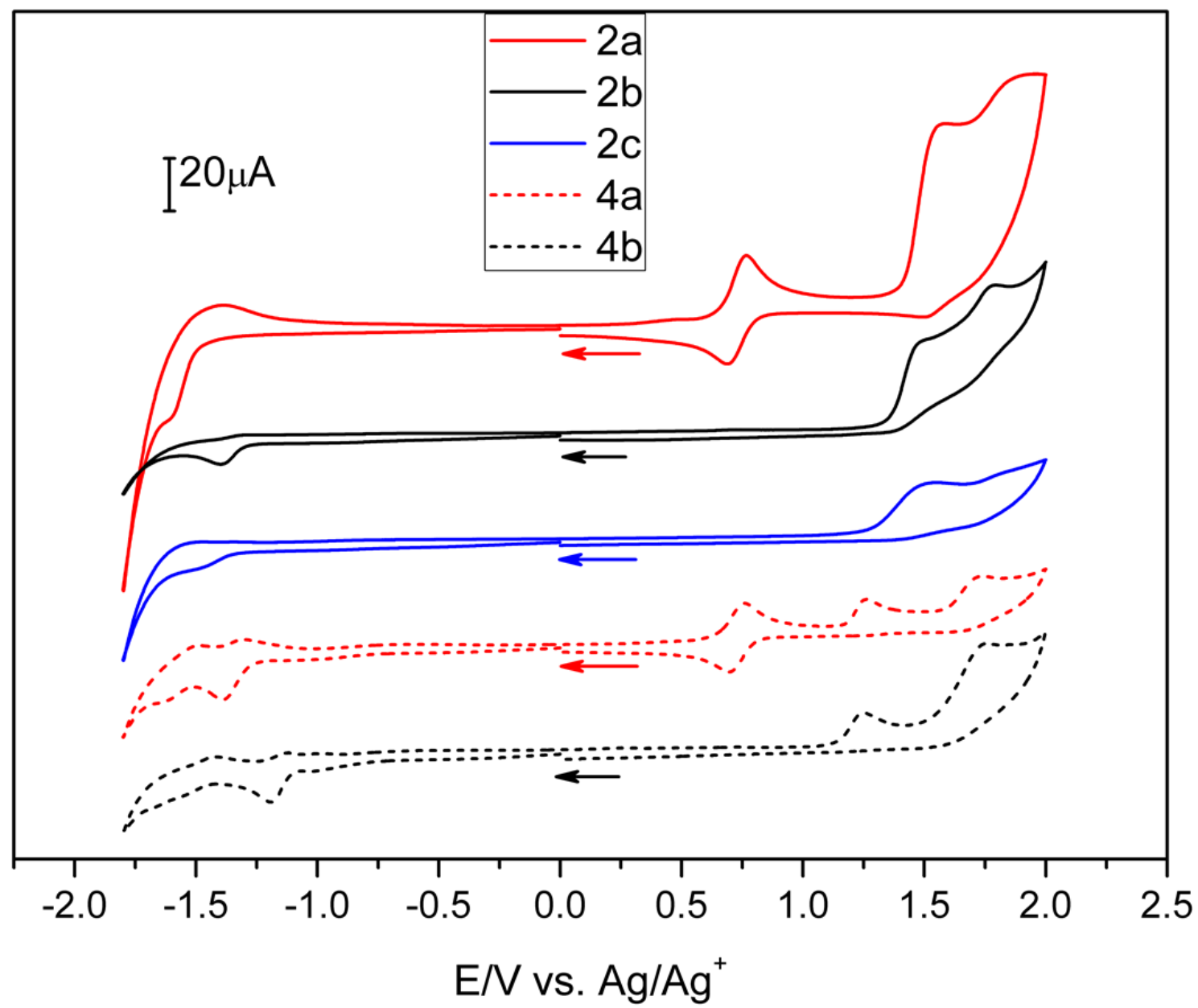

Figure 5. Cyclic voltammograms of 2 and 4 in $0.1 \mathrm{M}$ solution of $\mathrm{Bu}_{4} \mathrm{NBF}_{4}$ in $\mathrm{CH}_{3} \mathrm{CN}$; scan rate: $100 \mathrm{mV} \mathrm{s}^{-1}$, complex concentration: $1.0 \times 10^{-3} \mathrm{M}$.

\subsection{UV-Vis spectroscopy}

A large volume of work on the spectra of ferrocene and ferrocenyl chalcones has shown that multiple electronic transitions are hidden under an envelope running from the near-IR to the UV. ${ }^{17,28-30}$ In Figure 6, the absorption spectra of the chalconyl metallo-ligands 2a-c are presented. Two intense bands at 344 and $250 \mathrm{~nm}$ in the spectrum of the ferrocenyl chalcone $2 \mathbf{a}$ resemble those in the spectra of reported ferrocenyl chalcones. ${ }^{17}$ On this basis, 
the first absorption band is attributed to a charge transfer $\left(\mathrm{CT}, \varepsilon=16500 \mathrm{M}^{-1} \mathrm{~cm}^{-1}\right)$ and the band centered at $250 \mathrm{~nm}$ to a $\pi-\pi^{*}$ transition, characteristic of conjugated ketones. A shoulder at $280 \mathrm{~nm}$ is assigned to a $\mathrm{n}-\pi^{*}$ forbidden transition, ${ }^{17,28-31}$ Also in $\mathbf{2 a}$ spectrum, low intensity optical absorptions at wavelengths $\lambda_{\mathrm{ob}}>450 \mathrm{~nm}$, are associated with electronic transitions characterized by strong metal-centered character. ${ }^{28}$ In addition, a CT band with a higher intensity than $\mathrm{d}^{-\mathrm{d}^{*}}$ transitions is placed around the lower limit of this wavelength range. It is possible, therefore, that similar electronic transitions, $\mathrm{d}^{-\mathrm{d}^{*}}$ and CT, give rise to the asymmetric, $\lambda_{\max } \sim 480 \mathrm{~nm}$ absorption band in $\mathbf{2 a}$.
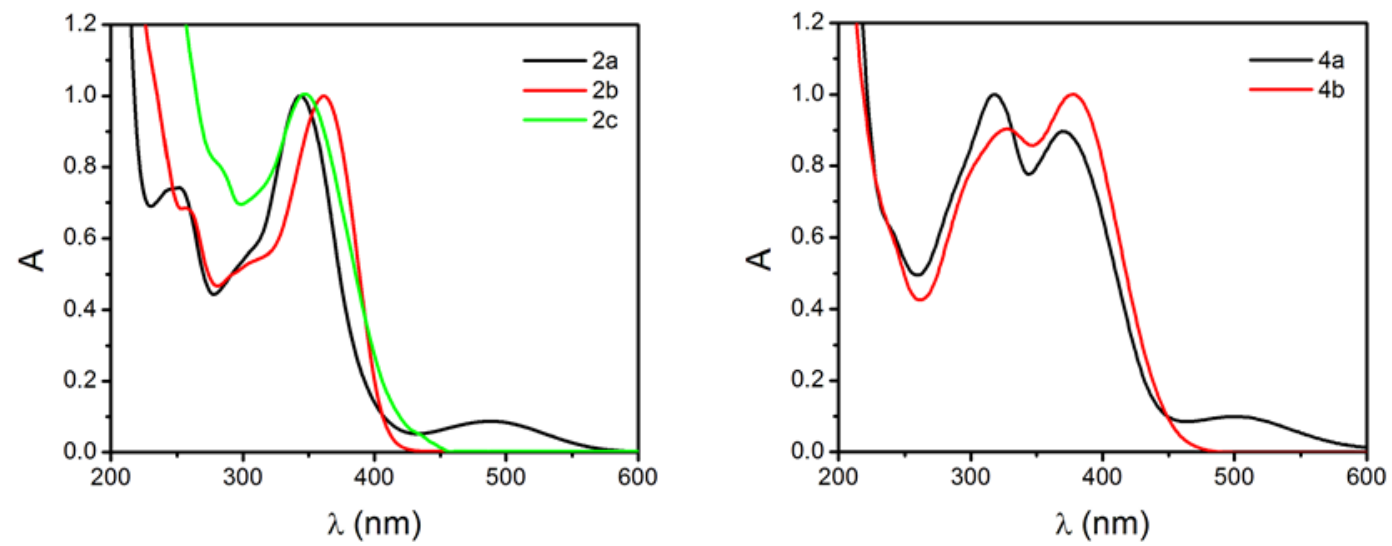

Figure 6. UV-Visible spectra of $\mathbf{2 a - c}$ and $\mathbf{4 a - b}$ in $\mathrm{CH}_{3} \mathrm{CN}$; metallo-ligands concentration: $10^{-5} \mathrm{M}$.

Some similarities can be drawn between the spectra of cyrhetrenyl and cymantrenyl chalcones and the spectrum of $\mathbf{2 a}$. Both chalconyl metallo-ligands $\mathbf{2 b}$ and $\mathbf{2 c}$ display CT absorptions at 362 and $350 \mathrm{~nm}$ respectively. Compared with $\mathbf{2 a}$, the organometallic moieties in $\mathbf{2 b}$ and $\mathbf{2 c}$ give rise to a bathochromic shift in the CT bands by 17 and $6 \mathrm{~kJ}$ respectively. This is the reverse of expectations based on the electrochemical potentials reported in section $\mathbf{2 . 4}$, since $\operatorname{Re}(\mathrm{I})$ and $\mathrm{Mn}(\mathrm{I})$ metallo-ligands are oxidized at more anodic potentials than ferrocenyl. It is conceivable then that the HOMO in $\mathbf{2 b - c}$, largely centered 
on the metal, is placed at a lower energy than in $\mathbf{2 a}$ resulting in the difference in electrochemical potentials. ${ }^{31-32}$ Although the ligand-centered $\pi^{*}$ orbitals participating in the CT transition must also be placed at lower energies than in $\mathbf{2 a}$, they will not affect the electrochemical potentials but result in the bathochromic shift of the CT transitions. Also contributing to the bathochromic shifts are the intrinsic nuclear reorganization energies associated with the Franck-Condon CT transitions of 2a-c. Differences between the $\mathbf{2 a}$ and 2b-c nuclear reorganizational energies may compensate to some extent for the lower energies of the $\pi^{*}$ orbitals in $\mathbf{2 b}$-c. Chalconyl metallo-ligands $\mathbf{2 b}, \mathbf{c}$ also display a band near $250 \mathrm{~nm}$ and a shoulder near $300 \mathrm{~nm}$ similar to those seen in the $\mathbf{2 a}$ spectrum that can be assigned to similar transitions.

The spectra of $\mathbf{4 a - b}$ in Fig. 6 share some common features with the spectra of $\mathbf{2 a - b}$, i.e., for $\lambda<350 \mathrm{~nm}$ and $\lambda>480 \mathrm{~nm}$. Some of the electronic transitions described earlier for $\mathbf{2 a}$, are expected to be present in these two regions. A deconvolution procedure shows new features with contributions from several electronic transitions with their origin in the conjugated imino group. A $\pi-\pi^{*}$ transition at $\lambda \sim 239 \mathrm{~nm}$ is the characteristic absorption observed in conjugated ketone spectra while the shoulder at $\sim 279 \mathrm{~nm}$ is assigned to an $\mathrm{n} \rightarrow \pi^{*}$ transition in the imino group. ${ }^{33}$ Intense bands with $\lambda_{\max }=317 \mathrm{~nm}$ and $371 \mathrm{~nm}$ are related to two different charge transfer transitions. The former is associated with a metal to ligand charge transfer transition while the latter with an imino to carbonyl charge transfer. Similar assignments for the optical transitions have been made with related organometallic chalcones. $^{17}$ 
2.6. Photobehavior of the Chalconyl metallo-ligands.

Work in the literature has shown that organometallic chalcones are photochemically active. Similar qualitative observations have been made with the organometallic chalcones studied in this work. Irradiation in different solvents $\left(\mathrm{CH}_{3} \mathrm{CN}, \mathrm{CH}_{3} \mathrm{OH}\right.$ or $\left.\mathrm{CH}_{2} \mathrm{Cl}_{2}\right)$ reveals that they undergo various metallo-ligand-dependent photochemical and photophysical processes. For example, while the $E \rightarrow Z$ photoisomerization is the premier photo-process of the cyrhetrenyl chalcone, for the ferrocenyl analogous the main process is photodecomposition. The dependence of the photo-processes on metallo-ligand, reaction medium and other conditions has shown that these photo-processes have neither simple photochemical nor simple photophysical mechanisms. With the aim of getting deeper insight into the stability of the rhenium compounds, dearated solution of $\mathbf{3 b}$ and $\mathbf{4 b}$ in acetonitrile were irradiated for $1 \mathrm{~min}(\lambda=254 \mathrm{~nm}, 8$ watt $)$ Fig. S25. The complex $\left(\eta^{5}-\mathrm{C}_{5} \mathrm{H}_{4}-\mathrm{CO}-\mathrm{CH}=\mathrm{CH}-\mathrm{C}_{6} \mathrm{H}_{4-}\right.$ $\mathrm{CHO}) \operatorname{Re}(\mathrm{CO})_{3}(\mathbf{3 b})$ exhibited a partial photoisomerization $E \rightarrow Z$, behavior that has been observed previously by Moore et al. for rhenium(I) tricarbonyl linked to amine or azacrown ether moieties by a styryl pryridine bridging ligand. These complexes can act as photoswitchable devices, and protonation can be used to control the $E \rightarrow Z$ photoisomerization reaction. ${ }^{34}$ The chalcone-imine $\mathbf{4 b}$, exhibited the same behaviour after 5 min of irradiation. Additional work is in progress to address the nature of the reaction mechanisms. ${ }^{35}$

\section{Conclusion}

A family of new ferrocenyl, cyrhetrenyl and cymantrenyl chalcone crown ether complexes has been synthesized with good to moderated yields, and fully characterized. 
The NMR spectra indicate that these compounds adopted an anti- $(E)$ conformation in solution, and this was confirmed by X-ray crystallography data for two of the complexes. The carboxaldehyde functionalized cyclopentadienyl, ferrocenyl and cyrhetrenyl, complexes 3a-b react with the precursor $4^{\prime}$-aminobenzo-15-crown-5 to yield the corresponding organometallic chalconyl-imine crown ether complexes $\mathbf{4 a - b}$, as a single isomer $(E, E)$. The UV-Vis spectra for the metallo-ligands 2a-c show intense CT bands, that are shifted depending on the nature of the metal center. Less intense bands are attributed to $\pi-\pi^{*}$ and $n \rightarrow \pi^{*}$ transitions, corresponding to the chalconyl fragment. Similar features were observed for metallo-ligands $\mathbf{4 a - b}$ in which more complex spectra result from the extension of the chromophore and the presence of the imine group.

\section{Experimental}

\subsection{General}

All preparations were carried out using standard Schlenk technique under a nitrogen atmosphere. All solvents were purified and dried by conventional methods and were distilled under nitrogen prior to use. The reagents, 4'-formylbenzo-15-crown-5, terephthalaldehyde, 4'-aminobenzo-15-crown-5 and $\left(\eta^{5}-\mathrm{C}_{5} \mathrm{H}_{4} \mathrm{C}(\mathrm{O}) \mathrm{CH}_{3}\right) \mathrm{Fe}\left(\eta^{5}-\mathrm{C}_{5} \mathrm{H}_{5}\right)$ (Aldrich) were used as received. Complexes $\left(\eta^{5}-\mathrm{C}_{5} \mathrm{H}_{5}\right) \operatorname{Re}(\mathrm{CO})_{3}, \quad\left(\eta^{5}-\right.$ $\left.\mathrm{C}_{5} \mathrm{H}_{4} \mathrm{C}(\mathrm{O}) \mathrm{CH}_{3}\right) \mathrm{Re}(\mathrm{CO})_{3} \quad(\mathbf{1 b})$ and $\left(\eta^{5}-\mathrm{C}_{5} \mathrm{H}_{4} \mathrm{C}(\mathrm{O}) \mathrm{CH}_{3}\right) \mathrm{Mn}(\mathrm{CO})_{3} \quad$ (1c) were synthesized following literature procedures. ${ }^{36}$ Infrared spectra were recorded in solid $(\mathrm{KBr})$ on a Perkin- 
Elmer FT-65 spectrophotometer. ${ }^{1} \mathrm{H}$ and ${ }^{13} \mathrm{C}$ NMR spectra were recorded on a Bruker AC 400 instrument. All ${ }^{1} \mathrm{H}$ NMR chemical shifts were referenced using the chemical shifts of residual solvent resonances. ${ }^{13} \mathrm{C}$ NMR chemical shifts were referenced to solvent peaks. Solutions of $\mathbf{2 a}, \mathbf{2 b}, \mathbf{4 a}$ and $\mathbf{4 b}$ were examined by electrospray mass spectroscopy with use of a Bruker microTOF instrument. Cyclic voltammetric (CV) studies were carried out at room temperature using a potentiostat (Metrohm Autolab potentiostat) in a three-electrode cell configuration with a $2 \mathrm{~mm} \mathrm{Pt}$ electrode, $\mathrm{Pt}$ coil counter electrode, and $\mathrm{Ag} / \mathrm{Ag}^{+}$ reference electrode. The inner solutions employed for the $\mathrm{Ag} / \mathrm{Ag}^{+}$reference electrodes were prepared with the same organic solvents as the electrochemical solutions. The working electrode was polished with 0.3 and $0.05 \mu \mathrm{m}$ alumina slurries, rinsed with distilled water $(18 \mathrm{M} \Omega \mathrm{cm})$ and acetone, and dried prior to use. All electrolyte solutions were thoroughly pre-purged using purified nitrogen gas before use. The measurements were carried out at $100 \mathrm{mV} / \mathrm{s}$ scan rate in dry and deoxygenated $\mathrm{CH}_{3} \mathrm{CN} / 0.1 \mathrm{M} \mathrm{Bu} \mathrm{BBF}_{4}$. The ferrocenium/ferrocene $\left(\mathrm{Fc}^{+/ 0}\right)$ couple served as internal reference and appeared at $+89 \mathrm{mV}$ (vs $\left.\mathrm{Ag} / \mathrm{Ag}^{+}\right)$for each experiment.

Tests of the organometallic chalcone photochemical activity were conducted following the procedure described below. Solutions of the organometallic chalcones were deaerated with streams of $\mathrm{N}_{2}$ and then irradiated for various periods. Some irradiation times were as short as several seconds. Rayonet lamps providing 254, 300 or $350 \mathrm{~nm}$ quasi-monochromatic light were used for the experiments. The progress of the photoreactions was assessed by means of the changes in the NMR and/or UV-Vis spectrum.

\subsection{Syntheses of chalconyl compounds}

\section{General procedure}


Acetyl derivative 1a-c (1 equiv.) and $\mathrm{NaOH}$ (3 equiv.) were dissolved in water/ethanol media (15 mL). After $0.5 \mathrm{~h}$. of reaction, the corresponding aldehyde (1 equiv.) dissolved in ethanol was added dropwise. The reaction mixture was stirred at room temperature and kept light protected (Scheme 1). The progress of the reaction was followed by thin layer chromatography until the reaction was completed. For $\mathbf{2 a}$ and $\mathbf{2 b}$ compounds once the reaction was completed, the mixture was neutralized with $2 \mathrm{M} \mathrm{HCl}$ solution. Then, $20 \mathrm{~mL}$ of $\mathrm{CH}_{2} \mathrm{Cl}_{2}$ was added and the product was extracted in the organic phase $(3 \times 15 \mathrm{~mL})$. Sodium sulphate was added to remove water excess. The mixture was filtered with Celite ${ }^{\circledR}$ and the solvent was evaporated to dryness. The residue was purified by column chromatography using neutral alumina and $1 \% \mathrm{~V} / \mathrm{V}$ methanol/ $\mathrm{CH}_{2} \mathrm{Cl}_{2}$ as eluent. On the other hand for $\mathbf{4 a}$ and $\mathbf{4 b}$ the reaction was stopped by cooling to $-18^{\circ} \mathrm{C}$. The solid was filtered through Celite ${ }^{\circledR}$, afterwards washed with Milli-Q water $(3 \times 5 \mathrm{~mL})$ and then with cold ethanol ( $3 \times 5 \mathrm{~mL}$ ). The product was dissolved with $\mathrm{CH}_{2} \mathrm{Cl}_{2}$ and isolated as crystalline solid after crystallization from hexane/ $\mathrm{CH}_{2} \mathrm{Cl}_{2}$ mixture.

\subsection{1. $\left(\eta^{5}-\mathrm{C}_{5} \mathrm{H}_{4} \mathrm{C}(\mathrm{O}) \mathrm{CH}=\mathrm{CH}-\right.$ benzo-15-crown-5)Fe$\left(\eta^{5}-\mathrm{C}_{5} \mathrm{H}_{5}\right)(2 \mathrm{a})$}

$200 \mathrm{mg}(0.86 \mathrm{mmol})$ of acetyl ferrocene (1a) was dissolved in $10 \% \mathrm{~V} / \mathrm{V}$ water/ethanol media and mixed with one equivalent of 4'-formylbenzo-15-crown-5 (Id). A red oily solid was obtained after evaporation of the solvent (yield: $291 \mathrm{mg}, 0.57 \mathrm{mmol}, 67 \%) . \mathrm{IR}(\mathrm{KBr}$, $v_{\mathrm{CO}} 1645 \mathrm{~cm}^{-1}, v_{\mathrm{C}=\mathrm{C}} 1583 \mathrm{~cm}^{-1} ;{ }^{1} \mathrm{H}$ NMR $\left(\mathrm{CDCl}_{3}\right) \delta: 3.77\left(\mathrm{~m}, 8 \mathrm{H}, \mathrm{OCH}_{2}\right), 3.95(\mathrm{~m}, 4 \mathrm{H}$, $\left.\mathrm{OCH}_{2}\right), 4.21\left(\mathrm{~m}, 9 \mathrm{H}, \mathrm{OCH}_{2}, \mathrm{C}_{5} \mathrm{H}_{5}\right), 4.57\left(\mathrm{t}, 2 \mathrm{H}, \mathrm{J}=1.9 \mathrm{~Hz}, \mathrm{C}_{5} \mathrm{H}_{4}\right), 4.91(\mathrm{t}, 2 \mathrm{H}, \mathrm{J}=1.9 \mathrm{~Hz}$ $\left.\mathrm{C}_{5} \mathrm{H}_{4}\right), 6.89\left(\mathrm{~d}, 1 \mathrm{H}, \mathrm{J}=8.3 \mathrm{~Hz}, \mathrm{C}_{6} \mathrm{H}_{3}\right), 6.97(\mathrm{~d}, 1 \mathrm{H}, \mathrm{J}=15.6 \mathrm{~Hz}, \mathrm{CH}=\mathrm{CH}), 7.16(\mathrm{~d}, 1 \mathrm{H}, \mathrm{J}=$ $\left.1.9 \mathrm{~Hz}, \mathrm{C}_{6} \mathrm{H}_{3} \mathrm{O}_{2}\right), 7.24\left(\mathrm{dd}, 1 \mathrm{H}, \mathrm{J}=8.3 \mathrm{~Hz}, \mathrm{~J}=1.9 \mathrm{~Hz}, \mathrm{C}_{6} \mathrm{H}_{3} \mathrm{O}_{2}\right) ; 7.72(\mathrm{~d}, 1 \mathrm{H}, \mathrm{J}=15,6 \mathrm{~Hz}$, $\mathrm{CH}=\mathrm{CH}) .{ }^{1} \mathrm{H}$ NMR $\left(\left(\mathrm{CD}_{3}\right)_{2} \mathrm{SO}\right) \delta: 3.60\left(\mathrm{~m}, 8 \mathrm{H}, \mathrm{OCH}_{2}\right) ; 3.79\left(\mathrm{~m}, 4 \mathrm{H}, \mathrm{OCH}_{2}\right) ; 4.09(\mathrm{~m}, 2 \mathrm{H}$, 
$\left.\mathrm{OCH}_{2}\right) ; 4.15\left(\mathrm{~m}, 2 \mathrm{H}, \mathrm{OCH}_{2}\right) ; 4.18\left(\mathrm{~s}, 5 \mathrm{H}, \mathrm{C}_{5} \mathrm{H}_{5}\right) ; 4.63\left(\mathrm{~s}_{\mathrm{br}}, 2 \mathrm{H}, \mathrm{C}_{5} \mathrm{H}_{4}\right) ; 5.04\left(\mathrm{~s}_{\mathrm{br}}, 2 \mathrm{H}, \mathrm{C}_{5} \mathrm{H}_{4}\right)$; $6.98\left(\mathrm{~d}, 1 \mathrm{H}, \mathrm{J}=8.3 \mathrm{~Hz}, \mathrm{C}_{6} \mathrm{H}_{3} \mathrm{O}_{2}\right) ; 7.28(\mathrm{~d}, 1 \mathrm{H}, \mathrm{J}=15.6 \mathrm{~Hz}, \mathrm{CH}=\mathrm{CH}) ; 7.35(\mathrm{dd}, 1 \mathrm{H}, \mathrm{J}=8.3$ $\left.\mathrm{Hz}, \mathrm{J}=1.3 \mathrm{~Hz}, \mathrm{C}_{6} \mathrm{H}_{3} \mathrm{O}_{2}\right) ; 7.46\left(\mathrm{~d}, 1 \mathrm{H}, \mathrm{J}=1.3 \mathrm{~Hz}, \mathrm{C}_{6} \mathrm{H}_{3} \mathrm{O}_{2}\right), 7.54(\mathrm{~d}, 1 \mathrm{H}, \mathrm{J}=15,6 \mathrm{~Hz}$ $\mathrm{CH}=\mathrm{CH}) .{ }^{13} \mathrm{C} \mathrm{NMR}\left(\mathrm{CDCl}_{3}\right) \delta: 69.2,69.7,69.8,69.9\left(4 \mathrm{~s}, \mathrm{OCH}_{2}\right) ; 70.1\left(\mathrm{~s}, \mathrm{C}_{5} \mathrm{H}_{4}\right) ; 70.5(\mathrm{~s}$, $\left.\mathrm{C}_{5} \mathrm{H}_{5}\right) ; 70.7,70.9,71.4,71.5\left(4 \mathrm{~s}, \mathrm{OCH}_{2}\right) ; 73.0\left(\mathrm{~s}, \mathrm{C}_{5} \mathrm{H}_{4}\right) ; 81.1\left(\mathrm{~s}, \mathrm{C}_{\mathrm{ipso}}, \mathrm{C}_{5} \mathrm{H}_{4}\right) ; 113.8,114.0$ $\left(2 \mathrm{~s}, \mathrm{C}_{6} \mathrm{H}_{3} \mathrm{O}_{2}\right) ; 121.4(\mathrm{~s}, \mathrm{CH}=\mathrm{CH}) ; 123.4,128.8\left(2 \mathrm{~s}, \mathrm{C}_{6} \mathrm{H}_{3} \mathrm{O}_{2}\right) ; 141.3(\mathrm{~s}, \mathrm{CH}=\mathrm{CH}) ; 149.6$, $151.7\left(2 \mathrm{~s}, \mathrm{C}_{6} \mathrm{H}_{3} \mathrm{O}_{2}\right) ; 193.3$ (s, CO). Mass spectrum HR-MS $\left(\mathrm{C}_{34} \mathrm{H}_{35} \mathrm{NO}_{6} \mathrm{Fe}\right) \mathrm{m} / \mathrm{z}: 507.1447$ $\left[\mathrm{M}^{+}\right.$]. Anal. (\%) calc. for $\mathrm{C}_{27} \mathrm{H}_{30} \mathrm{O}_{6} \mathrm{Fe}$ : C 64.04, H 5.97, O 18.96; found C 63.89, H 5.96, O 18.98. Single crystals suitable for X-ray diffraction were obtained by slow evaporation of a solution of $\mathbf{2 a}$ in diethyl ether. UV-Vis. $\lambda=344 \mathrm{~nm}$; extinction coefficient $\varepsilon=16500 \mathrm{M}^{-}$ ${ }^{1} \mathrm{~cm}^{-1}$ in $\mathrm{CH}_{3} \mathrm{CN}$.

\subsection{2. $\left(\eta^{5}-\mathrm{C}_{5} \mathrm{H}_{4} \mathrm{C}(\mathrm{O}) \mathrm{CH}=\mathrm{CH}-\mathrm{benzo}-15-\operatorname{crown}-5\right) \mathrm{Re}(\mathrm{CO})_{3}(2 \mathrm{~b})$}

$250 \mathrm{mg}(0.63 \mathrm{mmol})$ of acetyl cyrhetrene (1b) was dissolved in $10 \% \mathrm{~V} / \mathrm{V}$ water/ethanol media and mixed with one equivalent of 4'-formylbenzo-15-crown-5 (Id). A bright yellow oily solid was obtained after evaporation of the solvent (yield: $298 \mathrm{mg}, 0.45 \mathrm{mmol}, 72 \%$ ) IR $(\mathrm{KBr}), v_{\mathrm{ReCO}} 2021,1918 ; v_{\mathrm{CO}} 1653 ; v_{\mathrm{C}=\mathrm{C}} 1586 \mathrm{~cm}^{-1} ;{ }^{1} \mathrm{H} \mathrm{NMR}\left(\mathrm{CDCl}_{3}\right) \delta: 3.76(\mathrm{~m}, 8 \mathrm{H}$, $\left.\mathrm{OCH}_{2}\right), 3.92\left(\mathrm{~m}, 4 \mathrm{H}, \mathrm{OCH}_{2}\right), 4.80\left(\mathrm{~m}, 4 \mathrm{H}, \mathrm{OCH}_{2}\right), 5.44\left(\mathrm{t}, 2 \mathrm{H}, \mathrm{J}=2.2 \mathrm{~Hz}, \mathrm{C}_{5} \mathrm{H}_{4}\right), 6.11(\mathrm{t}$, $\left.2 \mathrm{H}, \mathrm{J}=2.2 \mathrm{~Hz}, \mathrm{C}_{5} \mathrm{H}_{4}\right), 6.76(\mathrm{~d}, 1 \mathrm{H}, \mathrm{J}=15.6 \mathrm{~Hz}, \mathrm{CH}=\mathrm{CH}), 6.87(\mathrm{~d}, 1 \mathrm{H}, \mathrm{J}=8.3 \mathrm{~Hz}$, $\left.\mathrm{C}_{6} \mathrm{H}_{3} \mathrm{O}_{2}\right), 7.10\left(\mathrm{~d}, 1 \mathrm{H}, \mathrm{J}=1.70 \mathrm{~Hz}, \mathrm{C}_{6} \mathrm{H}_{3}\right), 7.19\left(\mathrm{dd}, 1 \mathrm{H}, \mathrm{J}=8.3 \mathrm{~Hz}, \mathrm{~J}=1.7 \mathrm{~Hz}, \mathrm{C}_{6} \mathrm{H}_{3} \mathrm{O}_{2}\right)$, $7.74(\mathrm{~d}, 1 \mathrm{H}, \mathrm{J}=15.6 \mathrm{~Hz}, \mathrm{CH}=\mathrm{CH}) .{ }^{13} \mathrm{C} \mathrm{NMR}\left(\mathrm{CDCl}_{3}\right) \delta: 68.8,69.3,69.4,69.6\left(4 \mathrm{~s}, \mathrm{OCH}_{2}\right)$; 88.2, $85.3\left(2 \mathrm{~s}, \mathrm{C}_{5} \mathrm{H}_{4}\right) ; 97.9\left(\mathrm{~s}, \mathrm{C}_{\mathrm{ipso}}, \mathrm{C}_{5} \mathrm{H}_{4}\right) ; 113.2,113.4,118.4\left(3 \mathrm{~s}, \mathrm{C}_{6} \mathrm{H}_{3} \mathrm{O}_{2}\right) ; 123.9$ (s, $\mathrm{CH}=\mathrm{CH}) ; 127.6\left(\mathrm{~s}, \mathrm{C}_{6} \mathrm{H}_{3} \mathrm{O}_{2}\right) ; 144.9(\mathrm{~s}, \mathrm{CH}=\mathrm{CH}) ; 149.3,152.1\left(2 \mathrm{~s}, \mathrm{C}_{6} \mathrm{H}_{3} \mathrm{O}_{2}\right) ; 183.9$ (s, CO); 
192.2 (s, Re-CO). Mass spectrum HR-MS $\left(\mathrm{C}_{25} \mathrm{H}_{25} \mathrm{O}_{9} \mathrm{Re}\right) \mathrm{m} / \mathrm{z}: 657.1113\left[\mathrm{M}^{+}\right]$. Anal. (\%)

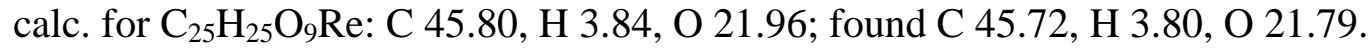

${ }^{1} \mathrm{H}$ NMR $\left(\left(\mathrm{CD}_{3}\right)_{2} \mathrm{SO}\right) \delta: 3.60\left(\mathrm{~m}, 8 \mathrm{H}, \mathrm{OCH}_{2}\right) ; 3.77\left(\mathrm{~m}, 4 \mathrm{H}, \mathrm{OCH}_{2}\right), 4.10\left(\mathrm{~m}, 4 \mathrm{H}, \mathrm{OCH}_{2}\right)$, $5.86\left(\mathrm{t}, 2 \mathrm{H}, \mathrm{J}=2.3 \mathrm{~Hz}, \mathrm{C}_{5} \mathrm{H}_{4}\right) ; 6.64\left(\mathrm{t}, 2 \mathrm{H}, \mathrm{J}=2.3 \mathrm{~Hz}, \mathrm{C}_{5} \mathrm{H}_{4}\right) ; 7.00(\mathrm{~d}, 1 \mathrm{H}, \mathrm{J}=8.4 \mathrm{~Hz}$ $\left.\mathrm{C}_{6} \mathrm{H}_{3} \mathrm{O}_{2}\right) ; 7,28(\mathrm{~d}, 1 \mathrm{H}, \mathrm{J}=15.5 \mathrm{~Hz}, \mathrm{CH}=\mathrm{CH}) ; 7.37(\mathrm{dd}, 1 \mathrm{H}, \mathrm{J}=8.4 \mathrm{~Hz}, \mathrm{~J}=1.8 \mathrm{~Hz}$ $\left.\mathrm{C}_{6} \mathrm{H}_{3} \mathrm{O}_{2}\right) ; 7.45\left(\mathrm{~d}, 1 \mathrm{H}, \mathrm{J}=1.8 \mathrm{~Hz}, \mathrm{C}_{6} \mathrm{H}_{3}\right), 7.62(\mathrm{~d}, 1 \mathrm{H}, \mathrm{J}=15.5 \mathrm{~Hz}, \mathrm{CH}=\mathrm{CH})$. Single crystals suitable for X-ray diffraction of were obtained by slow diffusion of hexane in a solution of 2b dissolved in a mixture $50 \% \mathrm{~V} / \mathrm{V}$ hexane $/ \mathrm{CH}_{2} \mathrm{Cl}_{2}$. UV-Vis. $\lambda=362 \mathrm{~nm}$; extinction coefficient $\varepsilon=23300 \mathrm{M}^{-1} \mathrm{~cm}^{-1}$ in $\mathrm{CH}_{3} \mathrm{CN}$.

\subsection{3. $\left(\eta^{5}-\mathrm{C}_{5} \mathrm{H}_{4} \mathrm{C}(\mathrm{O}) \mathrm{CH}=\mathrm{CH}-\right.$ benzo-15-crown-5) $\mathrm{Mn}(\mathrm{CO})_{3}(2 \mathrm{c})$}

$100 \mathrm{mg}(0.40 \mathrm{mmol})$ of acetyl cymantrene (1c) was dissolved in $10 \% \mathrm{~V} / \mathrm{V}$ water/ethanol media and mixed with one equivalent of 4'-formylbenzo-15-crown-5 (Id). A brown oily solid was obtained after evaporation of the solvent (yield: $95 \mathrm{mg}, 0.18 \mathrm{mmol}, 45 \%$ ). IR $\left(\mathrm{CH}_{2} \mathrm{Cl}_{2}\right) v_{\mathrm{MnCO}} 2029(\mathrm{~s}), 1947$ (s), $v_{\mathrm{CO}} 1659$ (w) $\mathrm{cm}^{-1} ;{ }^{1} \mathrm{H}$ NMR $\left(\mathrm{CD}_{3} \mathrm{CN}\right) \delta: 3.63$ (m, 8H, $\left.\mathrm{OCH}_{2}\right) ; 3.81\left(\mathrm{~m}, 4 \mathrm{H}, \mathrm{OCH}_{2}\right), 4.14\left(\mathrm{~m}, 4 \mathrm{H}, \mathrm{OCH}_{2}\right), 5.06\left(\mathrm{ps}, 2 \mathrm{H}, \mathrm{C}_{5} \mathrm{H}_{4}\right), 5.75(\mathrm{ps}, 2 \mathrm{H}$, $\left.\mathrm{C}_{5} \mathrm{H}_{4}\right), 7.06(\mathrm{~d}, 1 \mathrm{H}, \mathrm{J}=15.6 \mathrm{~Hz}, \mathrm{CH}=\mathrm{CH}), 6.96\left(\mathrm{~d}, 1 \mathrm{H}, \mathrm{J}=7,9 \mathrm{~Hz}, \mathrm{C}_{6} \mathrm{H}_{3} \mathrm{O}_{2}\right), 7.29(\mathrm{~m}, 2 \mathrm{H}, \mathrm{J}$ $\left.=1.70 \mathrm{~Hz}, \mathrm{C}_{6} \mathrm{H}_{3} \mathrm{O}_{2}\right) ; 7.66(\mathrm{~d}, 1 \mathrm{H}, \mathrm{J}=15.6 \mathrm{~Hz}, \mathrm{CH}=\mathrm{CH})$. Mass spectrum HR-MS $\left(\mathrm{C}_{25} \mathrm{H}_{25} \mathrm{O}_{9} \mathrm{Mn}\right) \mathrm{m} / \mathrm{z}: 525.0977\left[\mathrm{M}^{+}\right]$. Anal. (\%) calc. for $\mathrm{C}_{25} \mathrm{H}_{25} \mathrm{O}_{9} \mathrm{Mn}$ : C 57.26, H 4.81, O 27.85; found $\mathrm{C} 57.33, \mathrm{H} 4.91, \mathrm{O} 27.85$. UV-Vis. $\lambda=350 \mathrm{~nm}$; extinction coefficient $\varepsilon=$ $11800 \mathrm{M}^{-1} \mathrm{~cm}^{-1}$ in $\mathrm{CH}_{3} \mathrm{CN}$. 


\subsection{4. $\left(\eta^{5}-\mathbf{C}_{5} \mathbf{H}_{4} \mathbf{C}(\mathbf{O}) \mathbf{C H}=\mathbf{C H}-\mathrm{C}_{6} \mathbf{H}_{4} \mathbf{C H O}\right) \mathbf{F e}\left(\eta^{5}-\mathbf{C}_{5} \mathbf{H}_{5}\right)(3 a)$}

Acetyl ferrocene (1a) (250 mg, $1.09 \mathrm{mmol}), \mathrm{NaOH}$ (3 equiv.) and terephthalaldehyde (Ie)

(147 mg, 1.09 mmol). Purple solid, yield: 64\% (241 mg, $0.70 \mathrm{mmol}) . \mathrm{IR}(\mathrm{KBr}), v_{\mathrm{CO}} 1693$, $1649 \mathrm{~cm}^{-1} ; v_{\mathrm{C}=\mathrm{C}} 1591 \mathrm{~cm}^{-1} .{ }^{1} \mathrm{H}$ NMR $\left(\left(\mathrm{CD}_{3}\right)_{2} \mathrm{SO}\right) \delta: 4.24\left(\mathrm{~s}, 5 \mathrm{H}, \mathrm{C}_{5} \mathrm{H}_{5}\right) ; 4.71(\mathrm{t}, 2 \mathrm{H}, \mathrm{J}=1.8$ $\left.\mathrm{Hz}, \mathrm{C}_{5} \mathrm{H}_{4}\right) ; 5.09\left(\mathrm{t}, 2 \mathrm{H}, \mathrm{J}=1.8 \mathrm{~Hz}, \mathrm{C}_{5} \mathrm{H}_{4}\right) ; 7.59(\mathrm{~d}, 1 \mathrm{H}, \mathrm{J}=15.7 \mathrm{~Hz}, \mathrm{CH}=\mathrm{CH}) ; 7.70(\mathrm{~d}, 1 \mathrm{H}, \mathrm{J}$ $=15.7 \mathrm{~Hz}, \mathrm{CH}=\mathrm{CH}) ; 7.98\left(\mathrm{~d}, 2 \mathrm{H}, \mathrm{J}=8.2 \mathrm{~Hz}, \mathrm{C}_{6} \mathrm{H}_{4}\right) ; 8.10\left(\mathrm{~d}, 2 \mathrm{H}, \mathrm{J}=8.2 \mathrm{~Hz}, \mathrm{C}_{6} \mathrm{H}_{4}\right) ; 10.06(\mathrm{~s}$,

1H, CHO). ${ }^{13} \mathrm{C} \mathrm{NMR}\left(\left(\mathrm{CD}_{3}\right)_{2} \mathrm{SO}\right) \delta: 69.8\left(\mathrm{~s}, \mathrm{C}_{5} \mathrm{H}_{4}\right) ; 69.9\left(\mathrm{~s}, \mathrm{C}_{5} \mathrm{H}_{5}\right) ; 73.1\left(\mathrm{~s}, \mathrm{C}_{5} \mathrm{H}_{4}\right) ; 80.6(\mathrm{~s}$, $\left.\mathrm{C}_{\mathrm{ipso}}, \mathrm{C}_{5} \mathrm{H}_{4}\right) ; 126.5(\mathrm{~s}, \mathrm{CH}=\mathrm{CH}) ; 129.2,129.9\left(2 \mathrm{~s}, \mathrm{C}_{6} \mathrm{H}_{4}\right) ; 136.7,138.2\left(2 \mathrm{~s}, \mathrm{C}_{6} \mathrm{H}_{4}\right) ; 140.8(\mathrm{~s}$, $\mathrm{CH}=\mathrm{CH}) ; 191.9(\mathrm{~s}, \mathrm{CO}) ; 192.7$ (s, $\mathrm{CHO})$.

\subsection{5. $(\mathrm{CO})_{3} \operatorname{Re}\left(\eta^{5}-\mathrm{C}_{5} \mathrm{H}_{4} \mathrm{C}(\mathrm{O}) \mathrm{CH}=\mathrm{CH}-\mathrm{C}_{6} \mathrm{H}_{4}-\mathrm{CH}=\mathrm{CH}-(\mathrm{O}) \mathrm{C}^{-} \eta^{5}-\mathrm{C}_{5} \mathrm{H}_{4}\right) \operatorname{Re}(\mathrm{CO})_{3}\left(3 \mathrm{~b}^{\prime}\right)$}

Acetyl cyrhetrene (1b) (100 mg, $0.26 \mathrm{mmol}), \mathrm{NaOH}$ (3 equiv.) and terephtalaldehyde (Ie) (35 mg, $0.26 \mathrm{mmol})$. Yellow solid, yield: $68 \%$ (76 mg, $0.09 \mathrm{mmol})$. IR ( $\left.\mathrm{KBr}, \mathrm{cm}^{-1}\right), v_{\mathrm{ReCO}}$ $2020,1924, v_{\mathrm{CO}} 1698, v_{\mathrm{CO}} 1656, v_{\mathrm{C}=\mathrm{C}} 1595 .{ }^{1} \mathrm{H}$ NMR $\left(\left(\mathrm{CD}_{3}\right)_{2} \mathrm{SO}\right) \delta: 5.90(\mathrm{t}, 4 \mathrm{H}, \mathrm{J}=2.24$ $\left.\mathrm{Hz}, \mathrm{C}_{5} \mathrm{H}_{4}\right) ; 6.70\left(\mathrm{t}, 4 \mathrm{H}, \mathrm{J}=2.24 \mathrm{~Hz}, \mathrm{C}_{5} \mathrm{H}_{4}\right) ; 7.53(\mathrm{~d}, 2 \mathrm{H}, \mathrm{J}=15.6 \mathrm{~Hz}, \mathrm{CH}=\mathrm{CH}) ; 7.73(\mathrm{~d}, 2 \mathrm{H}$, $\mathrm{J}=15.6 \mathrm{~Hz}, \mathrm{CH}=\mathrm{CH}) ; 7.94\left(\mathrm{~s}, 4 \mathrm{H}, \mathrm{C}_{6} \mathrm{H}_{4}\right) .{ }^{13} \mathrm{C} \mathrm{NMR}\left(\left(\mathrm{CD}_{3}\right)_{2} \mathrm{SO}\right) \delta: 87.5,89.7\left(2 \mathrm{~s}, \mathrm{C}_{5} \mathrm{H}_{4}\right)$; $97.7\left(\mathrm{~s}, \mathrm{C}_{\mathrm{ipso}}, \mathrm{C}_{5} \mathrm{H}_{4}\right) ; 122.6(\mathrm{~s}, \mathrm{CH}=\mathrm{CH}) ; 129.5\left(\mathrm{~s}, \mathrm{C}_{6} \mathrm{H}_{4}\right) ; 136.5\left(\mathrm{~s}, \mathrm{C}_{6} \mathrm{H}_{4}\right) ; 142.3(\mathrm{~s}$, $\mathrm{CH}=\mathrm{CH}) ; 183.8$ (s, CO); 193.3 (s, Re-CO).

\section{Modification of procedure:}

\subsection{6 $\left(\eta^{5}-\mathrm{C}_{5} \mathrm{H}_{4} \mathrm{C}(\mathrm{O}) \mathrm{CH}=\mathrm{CH}-\mathrm{C}_{6} \mathrm{H}_{4} \mathrm{CHO}\right) \operatorname{Re}(\mathrm{CO})_{3}(3 \mathrm{~b})$}

Acetyl cyrhetrene (1b) (100 mg, 0.26 mmoles) and $\mathrm{NaOH}$ (3 equiv.) were dissolved in anhydrous ethanol $(15 \mathrm{~mL})$. After $0.5 \mathrm{~h}$. of reaction this solution was added dropwise to an 
ethanolic solution $(5 \mathrm{~mL})$ of terephthalaldehyde (Ie) $(70 \mathrm{mg}, 0.52 \mathrm{mmol})$ over a period of 2 h. with stirring at room temperature. After this time, the reaction mixture was stopped by neutralizing with solution $2 \mathrm{M} \mathrm{HCl}$ and it was extracted with $\mathrm{CH}_{2} \mathrm{Cl}_{2}(3 \times 15 \mathrm{~mL})$. The organic layer was dried with anhydrous $\mathrm{Na}_{2} \mathrm{SO}_{4}$ and removed by evaporation under reduced pressure. Column chromatography (silica gel), eluting with dichloromethane yielded the corresponding chalcone as yellow crystalline solid. yield: $63 \%$ (81 $\mathrm{mg}, 0.16 \mathrm{mmol})$. IR $(\mathrm{KBr}), v_{\mathrm{ReCO}} 2027,1928, v_{\mathrm{CO}} 1699,1658 \mathrm{~cm}^{-1} ; v_{\mathrm{C}=\mathrm{C}} 1604 \mathrm{~cm}^{-1} .{ }^{1} \mathrm{H}$ NMR $\left(\left(\mathrm{CD}_{3}\right)_{2} \mathrm{SO}\right) \delta$ : $5.91\left(\mathrm{t}, 2 \mathrm{H}, \mathrm{J}=2.1 \mathrm{~Hz}, \mathrm{C}_{5} \mathrm{H}_{4}\right) ; 6.72\left(\mathrm{t}, 2 \mathrm{H}, \mathrm{J}=2.1 \mathrm{~Hz}, \mathrm{C}_{5} \mathrm{H}_{4}\right) ; 7.61(\mathrm{~d}, 1 \mathrm{H}, \mathrm{J}=15.6 \mathrm{~Hz}$, $\mathrm{CH}=\mathrm{CH}) ; 7.76(\mathrm{~d}, 1 \mathrm{H}, \mathrm{J}=15.6 \mathrm{~Hz}, \mathrm{CH}=\mathrm{CH}) ; 7.98\left(\mathrm{~d}, 2 \mathrm{H}, \mathrm{J}=8.1 \mathrm{~Hz}, \mathrm{C}_{6} \mathrm{H}_{4}\right) ; 8.08(\mathrm{~d}, 2 \mathrm{H}, \mathrm{J}$ $\left.=8.1 \mathrm{~Hz}, \mathrm{C}_{6} \mathrm{H}_{4}\right) ; 10.06(\mathrm{~s}, 1 \mathrm{H}, \mathrm{CHO}) .{ }^{13} \mathrm{C} \mathrm{NMR}\left(\left(\mathrm{CD}_{3}\right)_{2} \mathrm{SO}-\mathrm{d}_{6}\right) \delta: 87.6,89.8\left(\mathrm{~s}, \mathrm{C}_{5} \mathrm{H}_{4}\right) ; 97.5$ $\left(\mathrm{s}, \mathrm{C}_{\mathrm{ipso}}, \mathrm{C}_{5} \mathrm{H}_{4}\right) ; 124.3(\mathrm{~s}, \mathrm{CH}=\mathrm{CH}) ; 129.5,129.9\left(2 \mathrm{~s}, \mathrm{C}_{6} \mathrm{H}_{4}\right) ; 137.2,139.9\left(2 \mathrm{~s}, \mathrm{C}_{6} \mathrm{H}_{4}\right) ; 141.8$ (s, $\mathrm{CH}=\mathrm{CH}) ; 183.7$ (s, CO); 192.7 (s, CHO); 193.3 (s, Re-CO).

\subsection{Synthesis of the chalconyl-imine complexes}

\section{General procedure:}

4'-aminobenzo-15-crown-5 (IId) was added to a solution of the corresponding organometallic chalcone $\mathbf{3 a - b}$ in dry toluene $(15 \mathrm{~mL})$. The reaction mixture was refluxed for $5 \mathrm{~h}$. with stirring and under nitrogen. After this time, the solvent was concentrated under reduced pressure to obtain 4 . The compounds were isolated as crystalline solids after crystallization from hexane/ $\mathrm{CH}_{2} \mathrm{Cl}_{2}$ mixture.

\subsection{1. $\left(\eta^{5}-\mathrm{C}_{5} \mathrm{H}_{4} \mathrm{C}(\mathrm{O}) \mathrm{CH}=\mathrm{CH}-\mathrm{C}_{6} \mathrm{H}_{4} \mathrm{CH}=\mathrm{N}-\right.$ benzo-15-crown-5)Fe $\left(\eta^{5}-\mathrm{C}_{5} \mathrm{H}_{5}\right)(4 \mathrm{a})$ 4'-aminobenzo-15-crown-5 (IId) $\quad(50 \quad \mathrm{mg}, \quad 0.17 \mathrm{mmol})$ and $\left(\eta^{5}-\mathrm{C}_{5} \mathrm{H}_{4} \mathrm{C}(\mathrm{O}) \mathrm{CH}=\mathrm{CH}-\right.$ $\left.\mathrm{C}_{6} \mathrm{H}_{4} \mathrm{CHO}\right) \mathrm{Fe}\left(\eta^{5}-\mathrm{C}_{5} \mathrm{H}_{5}\right)(\mathbf{3 a}) \quad(61 \mathrm{mg}, 0.17 \mathrm{mmol})$. Red solid, yield: 88\% (95 mg, 0.15 mmoles). IR $\left(\mathrm{KBr}, \mathrm{cm}^{-1}\right), v_{\mathrm{CO}} 1650, v_{\mathrm{C}=\mathrm{C}} 1589, v_{\mathrm{C}=\mathrm{N}} 1620 .{ }^{1} \mathrm{H} \mathrm{NMR}\left(\left(\mathrm{CD}_{3}\right)_{2} \mathrm{SO}\right) \delta: 3.63(\mathrm{~s}$,}


$\left.8 \mathrm{H}, \mathrm{OCH}_{2}\right), 3.79\left(\mathrm{~m}, 4 \mathrm{H}, \mathrm{OCH}_{2}\right) ; 4.08\left(\mathrm{~m}, 2 \mathrm{H}, \mathrm{OCH}_{2}\right) ; 4.13\left(\mathrm{~m}, 2 \mathrm{H}, \mathrm{OCH}_{2}\right) ; 4.25(\mathrm{~s}, 5 \mathrm{H}$, $\left.\mathrm{C}_{5} \mathrm{H}_{5}\right) ; 4.70\left(\mathrm{t}, 2 \mathrm{H}, \mathrm{J}=1.8 \mathrm{~Hz}, \mathrm{C}_{5} \mathrm{H}_{4}\right) ; 5.09\left(\mathrm{t}, 2 \mathrm{H}, \mathrm{J}=1.8 \mathrm{~Hz}, \mathrm{C}_{5} \mathrm{H}_{4}\right) ; 6.93(\mathrm{dd}, 1 \mathrm{H}, \mathrm{J}=8.4$; $\left.2.2 \mathrm{~Hz}, \mathrm{C}_{6} \mathrm{H}_{3} \mathrm{O}_{2}\right) ; 7.00\left(\mathrm{~d}, 1 \mathrm{H}, \mathrm{J}=8.4 \mathrm{~Hz}, \mathrm{C}_{6} \mathrm{H}_{3} \mathrm{O}_{2}\right) ; 7.04\left(\mathrm{~d}, 1 \mathrm{H}, \mathrm{J}=2.2 \mathrm{~Hz}, \mathrm{C}_{6} \mathrm{H}_{3} \mathrm{O}_{2}\right) ; 7.54$ $(\mathrm{d}, 1 \mathrm{H}, \mathrm{J}=15.7 \mathrm{~Hz}, \mathrm{CH}=\mathrm{CH}) ; 7.68(\mathrm{~d}, 1 \mathrm{H}, \mathrm{J}=15.7 \mathrm{~Hz}, \mathrm{CH}=\mathrm{CH}) ; 8.00$ (dd overlap, 4H, $\left.\mathrm{C}_{6} \mathrm{H}_{4}\right) ; 8.73(\mathrm{~s}, 1 \mathrm{H}, \mathrm{CH}=\mathrm{N}) .{ }^{13} \mathrm{C} \mathrm{NMR}\left(\left(\mathrm{CD}_{3}\right)_{2} \mathrm{SO}\right) \delta: 68.4,68.7,68.8,68.9,69.7(5 \mathrm{~s}$, $\left.\mathrm{OCH}_{2}\right) ; 69.8\left(\mathrm{~s}, \mathrm{C}_{5} \mathrm{H}_{4}\right) ; 69.9\left(\mathrm{~s}, \mathrm{C}_{5} \mathrm{H}_{5}\right) ; 70.5,70.5\left(2 \mathrm{~s}, \mathrm{OCH}_{2}\right) ; 72.9\left(\mathrm{~s}, \mathrm{C}_{5} \mathrm{H}_{4}\right) ; 80.7\left(\mathrm{~s}, \mathrm{C}_{\mathrm{ipso}}\right.$ $\left.\mathrm{C}_{5} \mathrm{H}_{4}\right) ; 106.9,113.9,114.2\left(3 \mathrm{~s}, \mathrm{C}_{6} \mathrm{H}_{3} \mathrm{O}_{2}\right) ; 124.8(\mathrm{~s}, \mathrm{CH}=\mathrm{CH}) ; 128.8,129.1\left(2 \mathrm{~s}, \mathrm{C}_{6} \mathrm{H}_{4}\right)$; 137.4, $137.6\left(2 \mathrm{~s}, \mathrm{C}_{6} \mathrm{H}_{4}\right) ; 138.9(\mathrm{~s}, \mathrm{CH}=\mathrm{CH}) ; 144.4,147.5,149.0\left(3 \mathrm{~s}, \mathrm{C}_{6} \mathrm{H}_{3} \mathrm{O}_{2}\right) ; 157.8(\mathrm{~s}$, $\mathrm{CH}=\mathrm{N}) ; 191.9$ (s, CO). Mass spectrum HR-MS $\left(\mathrm{C}_{34} \mathrm{H}_{35} \mathrm{NO}_{6} \mathrm{Fe}\right) \mathrm{m} / \mathrm{z}: 610.1863\left[\mathrm{M}^{+}\right]$. Anal (\%) Cal. for $\mathrm{C}_{34} \mathrm{H}_{35} \mathrm{NO}_{6} \mathrm{Fe}$ : C 67.00, H 5.78; Found: C 64.53, H 5.53. UV-Vis. $\lambda=317 \mathrm{~nm}$; extinction coefficient $\varepsilon=26600 \mathrm{M}^{-1} \mathrm{~cm}^{-1}$ and $\lambda=371 \mathrm{~nm}$; extinction coefficient $\varepsilon=24000$ $\mathrm{M}^{-1} \mathrm{~cm}^{-1}$ in $\mathrm{CH}_{3} \mathrm{CN}$.

\subsection{2. $\left(\eta^{5}-\mathrm{C}_{5} \mathrm{H}_{4} \mathrm{C}(\mathrm{O}) \mathrm{CH}=\mathrm{CH}-\mathrm{C}_{6} \mathrm{H}_{4} \mathrm{CH}=\mathrm{N}-\right.$ benzo-15-crown-5) $\mathrm{Re}(\mathrm{CO})_{3}(4 \mathrm{~b})$}

4'-aminobenzo-15-crown-5 (IId) (40 mg, $0.14 \mathrm{mmol})$ and $\left(\eta^{5}-\mathrm{C}_{5} \mathrm{H}_{4} \mathrm{C}(\mathrm{O}) \mathrm{CH}=\mathrm{CH}-\right.$ $\left.\mathrm{C}_{6} \mathrm{H}_{4} \mathrm{CHO}\right) \mathrm{Re}(\mathrm{CO})_{3}(\mathbf{3 b})(70 \mathrm{mg}, 0.14 \mathrm{mmol})$. Yellow solid, yield: $78 \%$ (83 mg, 0.11 mmoles). IR $\left(\mathrm{KBr}, \mathrm{cm}^{-1}\right), v_{\mathrm{ReCO}} 2026,1926 ; v_{\mathrm{CO}} 1660 ; v_{\mathrm{C}=\mathrm{C}} 1596 ; v_{\mathrm{C}=\mathrm{N}} 1620 .{ }^{1} \mathrm{H} \mathrm{NMR}$ $\left(\left(\mathrm{CD}_{3}\right)_{2} \mathrm{SO}-\mathrm{d}_{6}\right) \delta: 3.63\left(\mathrm{~s}, 8 \mathrm{H}, \mathrm{OCH}_{2}\right) ; 3.79\left(\mathrm{~m}, 4 \mathrm{H}, \mathrm{OCH}_{2}\right) ; 4.07\left(\mathrm{~m}, 2 \mathrm{H}, \mathrm{OCH}_{2}\right) ; 4.12(\mathrm{~m}$ $\left.2 \mathrm{H}, \mathrm{OCH}_{2}\right) ; 5.90\left(\mathrm{t}, 2 \mathrm{H}, \mathrm{J}=2,3 \mathrm{~Hz}, \mathrm{C}_{5} \mathrm{H}_{4}\right) ; 6.71\left(\mathrm{t}, 2 \mathrm{H}, \mathrm{J}=2.3 \mathrm{~Hz}, \mathrm{C}_{5} \mathrm{H}_{4}\right) ; 6.92(\mathrm{dd}, 1 \mathrm{H}, \mathrm{J}=$ 2.2; $\left.8.4 \mathrm{~Hz}, \mathrm{C}_{6} \mathrm{H}_{3} \mathrm{O}_{2}\right) ; 6.99\left(\mathrm{~d}, 1 \mathrm{H}, \mathrm{J}=8.4 \mathrm{~Hz}, \mathrm{C}_{6} \mathrm{H}_{3} \mathrm{O}_{2}\right) ; 7.04\left(\mathrm{~d}, 1 \mathrm{H}, \mathrm{J}=2.2 \mathrm{~Hz}, \mathrm{C}_{6} \mathrm{H}_{3} \mathrm{O}_{2}\right)$; $7.56(\mathrm{~d}, 1 \mathrm{H}, \mathrm{J}=15.6 \mathrm{~Hz}, \mathrm{CH}=\mathrm{CH}) ; 7.75(\mathrm{~d}, 1 \mathrm{H}, \mathrm{J}=15.6 \mathrm{~Hz}, \mathrm{CH}=\mathrm{CH}) ; 7.98$ (s, br, 4H, $\left.\left.\mathrm{C}_{6} \mathrm{H}_{4}\right) ; 8.72(\mathrm{~s}, 1 \mathrm{H}, \mathrm{CH}=\mathrm{N}).\right) .{ }^{13} \mathrm{C} \mathrm{NMR}\left(\left(\mathrm{CD}_{3}\right)_{2} \mathrm{SO}\right) \delta: 68.4,68.7,68.8,68.9,69.7,69,8$, $70,5\left(7 \mathrm{~s}, \mathrm{OCH}_{2}\right) ; 87.5,89.6\left(2 \mathrm{~s}, \mathrm{C}_{5} \mathrm{H}_{4}\right) ; 97.8\left(\mathrm{~s}, \mathrm{C}_{\mathrm{ipso}}, \mathrm{C}_{5} \mathrm{H}_{4}\right) ; 106.8,113.9,114.2(3 \mathrm{~s}$, $\left.\mathrm{C}_{6} \mathrm{H}_{3} \mathrm{O}_{2}\right) ; 122.5(\mathrm{~s}, \mathrm{CH}=\mathrm{CH}) ; 128.8,129.4,129.5,130.0\left(4 \mathrm{~s}, \mathrm{C}_{6} \mathrm{H}_{4}\right) ; 136.7,138.2(2 \mathrm{~s}$, 
$\left.\mathrm{C}_{6} \mathrm{H}_{4}\right) ; 142.5$ (s, $\left.\mathrm{CH}=\mathrm{CH}\right) ; 144.4,147.6,149.0\left(3 \mathrm{~s}, \mathrm{C}_{6} \mathrm{H}_{3} \mathrm{O}_{2}\right) ; 157.7(\mathrm{~s}, \mathrm{CH}=\mathrm{N}) ; 183.7$ (s, CO); 193.3 (s, Re-CO). Mass spectrum HR-MS $\left(\mathrm{C}_{32} \mathrm{H}_{30} \mathrm{NO}_{9} \mathrm{Re}\right) \mathrm{m} / \mathrm{z}: 760.1582\left[\mathrm{M}^{+}\right]$. Anal (\%) Cal. for $\mathrm{C}_{32} \mathrm{H}_{30} \mathrm{NO}_{9}$ Re: C 50.65, H 3.98; Found: C 50.24, H 4.02. UV-Vis. $\lambda=327 \mathrm{~nm}$; extinction coefficient $\varepsilon=25500 \mathrm{M}^{-1} \mathrm{~cm}^{-1}$ and $\lambda=377 \mathrm{~nm}$; extinction coefficient $\varepsilon=28200$ $\mathrm{M}^{-1} \mathrm{~cm}^{-1}$ in $\mathrm{CH}_{3} \mathrm{CN}$.

\subsection{X-ray Crystallography.}

The samples were mounted on a Kapton loop using Paratone-N hydrocarbon oil. For four structures, X-ray intensity data were recorded on a Bruker APEX-II ${ }^{37} \mathrm{CCD}$ area detector with graphite monochromated Mo-KR radiation. The data were collected at a temperature of 120(2) K. Synchrotron data for the remaining structure were collected at Beamline 11.3.1 at the Advanced Light Source at Lawrence Berkeley National Laboratory. Data were recorded at a temperature of 120 (2) and150(2) K using the APEX-2 software suite on a Bruker APEX-II detector mounted on a D8 goniometer using radiation tuned to $0.7749 \AA$ $(17.000 \mathrm{keV})$ monochromated through a channel-cut SI- $\langle 111\rangle$ crystal. Frames corresponding to an arbitrary sphere of data were collected using a combination $\omega$ and $\varphi$ scans of $0.3^{\circ}$. Data were integrated by the program SAINT $^{38}$ and were corrected for Lorentz, polarization, and absorption effects based on a comparison of redundant and equivalent reflections using SADABS..$^{39}$ Data were analyzed for agreement, and the space group was determined using XPREP. ${ }^{40}$ No decay correction was applied. The structure was solved by direct methods ${ }^{41}$ and expanded using Fourier techniques. ${ }^{42}$ Neutral atom scattering factors for the radiation used were determined from those of Kissel and Pratt 
(XDISP). ${ }^{43}$ Non-hydrogen atoms were refined anisotropically. Hydrogen atoms were included in calculated positions but were not refined. More details of the data collections and structure refinements are presented in Table 1.

\section{Author contributions}

The manuscript was written through contributions of all authors. All authors have given approval to the final version of the manuscript.

\section{Acknowledgments}

We thank the "Fondo de Desarrollo Científico y Tecnológico" (FONDECYT) Chile, for financial support under project $\mathrm{N}^{\mathrm{O}}$ 1151156; VRIDEI-Usach. N.A. and T.M acknowledge CONICYT for a doctoral fellowship and VRIDEI-Usach project No 0216GG-Postdoctoral. Samples for synchrotron crystallographic analysis were submitted through the SCrALS (Service Crystallography at Advanced Light Source) program. Crystallographic data were collected at Beamline 11.3.1 at the Advanced Light Source (ALS), Lawrence Berkeley National Laboratory. The ALS is supported by the U.S. Dept. of Energy, Office of Energy Sciences, under contract DE-AC02-05CH11231. Part of this work was carried out in the Notre Dame Radiation Laboratory (NDRL). The NDRL is supported by the Division of

Chemical Sciences, Geosciences and Biosciences, Basic Energy Sciences, Office of Science, United States Department of Energy through grant number DE-FC02-04ER15533. This is contribution number NDRL 5127.

\section{Appendix. Supplementary material}

CCDC 1485208-1485211 contains the supplementary crystallographic data for this paper. This data can be obtained free of charge from The Cambridge Crystallographic Data Centre via www.ccdc.cam.ac.uk/data_request/cif.

\section{References.}


1.- for some examples: (a) M. C. Gimeno, H. Goitia, A. Laguna, M. E. Luque, M. D. Villacampa, C. Sepúlveda, M. J. Meireles, Inorg. Biochem. 105 (2011) 1373. (b) M. ElHussieny, H. A. A. Yosef, M. R. H. Mahran, N. M. Ibrahim, Heterocycl. Commun. 22 (2016) 69. (c) F. J. Smit, J. J. Bezuidenhout, C. C. Bezuidenhout, D. D. N’Da, Med. Chem. Res. 25 (2016) 568. (d) P. Caboni, N. Aissani, M. Demurtas, N. Ntalli, V. Onnis, Pest. Manag. Sci. 72 (2016), 125. (e) S. Dong, X. Liu, X. Chen, F. Mei, Y. Zhang, B. Gao, L. Lin, X. Feng, J. Am. Chem. Soc. 132 (2010) 10650. (f) Y. Cai, X. Liu, J. Jiang, W. Chen, L. Lin, X. Feng, J. Am. Chem. Soc. 133 (2011) 5636. (g) V. Nair, S. Vellalath, M. Poonoth, E. Suresh, J. Am. Chem. Soc. 128 (2006) 8736. (h) E. Rohrmann, R. G. Jones, H. A. Shonle, J. Am. Chem. Soc. 66 (1944) 1856 (i) F. M. Menger, J. H. Smith, J. Am. Chem. Soc. 91 (1969) 4211. (j) K. N. Tiwari, J. -P. Monserrat, A. Hequet, C. Ganem-Elbaz, T. Cresteil, G. Jaouen, A. Vessières, E. A. Hillard, C. Jolivalt, Dalton Trans. 41 (2012) 6451.

2.- Z. -L. Shen, S. -J. Ji, W. -J. Zhou, Synth. Commun. 35 (2005) 1903.

3.- W. -J. Zhou, S. -J. Ji, Z. -L. Shen, J. Organomet. Chem. 691 (2006) 1356.

4.- V. Zsoldos-Mády, A. Csámpai, R. Szabó, E. Mészáros-Alapi, J. Pásztor, F. Hudecz, P. Sohár, Chem. Med. Chem. 1 (2006) 1119.

5.- L. -P. Guan, B. -Y. Liu, Eur. J. Med. Chem. 121 (2016) 47.

6.- M. Satyanarayana, P. Tiwari, B. K. Tripathi, A. K. Srivastavab, R. Pratap, Bioorg. Med. Chem. 12 (2004) 883.

7.- N. Selvakumar, G. Kumar, A. Azhagan, G. Rajulu, S. Sharma, M. Kumar, J. Das, J. Iqbal, S. Trehan, Eur. J. Med. Chem. 42 (2007) 538.

8.- R. N. Gacche, N. A. Dhole, S. G. Kamble, B. P. Bandgar, J. Enzym. Inhib. Med. Chem. 23 (2008) 28.

9.- X. Wu, P. Wilairatb, M. -L. Goa, Bioorg. Med. Chem. Lett. 12 (2002) 2299.

10.- J. -P. Monserrat, R. I. Al-Safi, K. N. Tiwari, L. Quentin, G. G. Chabot, A. Vessières, G. Jaouen, N. Neamati, E. A. Hillard, Bioorg. Med. Chem. Lett. 21 (2011) 6195.

11.- S. Mishra, V. Tirkey, A. Ghosha, H. R. Dashb, S. Dasb, M. Shukla, S. Saha, S. M. Mobind, S. Chatterjee, J. Mol. Struct. 1085 (2015) 162.

12.- R. Arancibia, C. Biot, G. Delaney, P. Roussel, A. Pascual, B. Pradines, A. H. Klahn, J. Organomet. Chem. 743 (2013) 143. 
13.- (a) J. Maynadie, B. Delavaux-Nicot, D. Lavabre, B. Donnadieu, J.- C. Daran, A. Sournia-Saquet, Inorg. Chem. 43 (2004) 2064. (b) B. Delavaux-Nicot, J. Maynadié, D. Lavabre, C. Lepetit, B. Donnadieu, Eur. J. Inorg. Chem. 12 (2005) 2493. (c) B. DelavauxNicot, J. Maynadie, D. Lavabre, S. Fery-Forgues, Inorg. Chem. 45 (2006) 5691. (d) B. Delavaux-Nicot, J. Maynadie, D. Lavabre, S. Fery-Forgues, J. Organomet. Chem. 692 (2007) 874. (e) B. Delavaux-Nicot, J. Maynadie, D. Lavabre, S. Fery-Forgues, J. Organomet. Chem. 692 (2007) 3351.

14.- M. -J. Li, C.-C. Ko, G.-P. Duan, N. Zhu, V. W. -W. Yam, Organometallics 26 (2007) 6091.

15.- F. Godoy, A. Gómez, N. Agurto, M. Muñoz, R. Segura, C. P. Silva, J. Pavez, J. H. Zagal, A. H. Klahn, M. Fuentealba, A. Ibañez, M. T. Garland, J. Organomet. Chem. 788 (2015) 42.

16.- J. Grealis, H. Müller-Bunz, Y. Ortin, M. Casey, M. McGlinchey, Eur. J. Org. Chem. 2 (2013) 332.

17.- B. Delavaux-Nicot, S. Fery-Forgues, Eur. J. Inorg. Chem. 10 (1999) 1821.

18.- W. Suh, H. Jeon, J. Y. Lee, C. M. Lim, S. K. Lee, D. Y. Noh, Bull. Korean Chem. Soc. 33 (2012) 443.

19.- N. Baartzes, T. Stringer, R. Seldon, D. F. Warner, C. De Kock, P. J. Smith, G. S. Smith, J. Organomet. Chem. 809 (2016) 79.

20.- R. Arancibia, F. Dubar, B. Pradines, D. Dive, A. H. Klahn, C. Biot, Bioorg. Med. Chem. 18 (2010) 8085.

21.- P. D. Beer, H. Sikanyika, Polyhedron 9 (1990) 1091.

22.- R. Arancibia, A. H. Klahn, G. E. Buono-Core, D. Contreras, G. Barriga, C. Olea-Azar, M. Lapier, J. D. Maya, A. Ibañez, M. T. Garland, J. Organomet. Chem. 743 (2013) 49.

23.- Bruker AXS. (2014). APEX-2. Bruker-Nonius AXS, Madison, Wisconsin, USA.

24.- G. M. Sheldrick, Acta Cryst. A71 (2015) 3.

25.- G. M. Sheldrick, Acta Cryst. C71 (2015) 3.

26.- M. Zora, O. Velioglu, J. Organomet. Chem. 693 (2008) 2159.

27.- K. Lam, W. E. Geiger, J. Organomet. Chem. 817 (2016) 15.

28.- A. T. Armstrong, F. Smith, E. Elder, S. P. McGlynn, J. Chem. Phys. 46 (1967) 4321.

29.- U. Salzner, J. Chem. Theory Comput. 9 (2013) 4064. 
30.- D. Nielson, M. Farmer, H. Eyring, J. Phys. Chem. 80 (1976) 717.

31.- Albright, T.A.; Burdett, J.K.; Whangbo, M-H. Orbital Interactions in Chemistry, John Wiley \& Sons, New York, 1985.

32.- Albright, T.A.; Burdett, J.K. Problems in Molecular Orbital Theory, Oxford University Press, New York, 1992.

33.- N. Marcotte, S. Fery-Forgues, J. Chem. Soc. Perkin Trans. 2 (2000) 1711.

34.- J.D. Lewis, R.N. Perutz, J.N. Perutz, Chem. Commun. 19 (2000), 1865.

35.- (a) T. Maldonado, G. Ferraudi, A.G. Lappin, F. Godoy, J. Phys. Chem. in press. (b) T.

Maldonado, F. Godoy, G. Ferraudi, A.G. Lappin. Unpublished results.

36.- S. S. Jones, M. D. Rausch, T. E. Bitterwolf, J. Organomet. Chem. 396 (1990) 279.

37.- APEX-2 v2009-1: Suite for X-ray structure data collection and determination; Bruker Analytical X-ray Systems, Inc.: Madison, WI, 2009.

38.- SAINT: SAX Area-Dectector Integration Program; Bruker Analytical X-ray Systems, Inc.: Madison, WI, 2009.

39.- SADABS: Siemens Area Detector ABSorption correction program; George Sheldrick, University of Göttingen: Göttingen, Germany, 2008.

40.- XPREP (v 6.14): Part of the SHELXTL Crystal Structure Determination Package; Bruker Analytical X-ray Systems, Inc.: Madison, WI, 1995.

41.- SHELXS: Program for the Solution of X-ray Crystal Structures; George Sheldrick, University of Göttingen: Göttingen, Germany, 2008.

42.- SHELXL: Program for the Refinement of X-ray Crystal Structures; George Sheldrick, University of Göttingen: Göttingen, Germany, 2008.

43.- XDISP: X-ray Anomalous Dispersion part of the WinGX package; L. Kissel, R. H. Pratt, Acta Crystallogr. A46 (1990) 170; L. J. Farrugia, J. Appl. Crystallogr. 32 (1999) 837. 


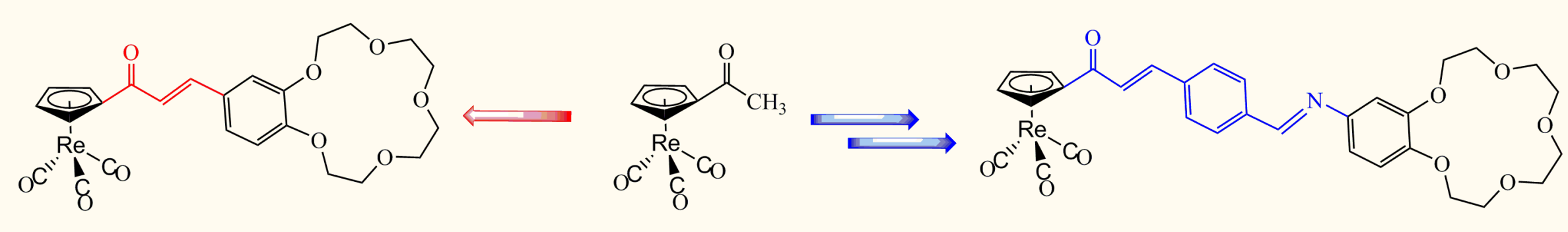

